\title{
Genetic assessment of the pomological classification of plum Prunus domestica $L$. accessions sampled across Europe
}

Article

Accepted Version

Gasi, F., Sehic, J., Grahic, J., Hjeltnis, S. H., Ordidge, M., Benedikova, D., Blouin-Delmas, M., Drogoudi, P., Giovannini, D., Hofer, M., Kovacs, S., Kahu, K., Lacis, G., Lateur, M., Toldam-Andersen, T. B., Ognjanov, V. and Nybom, H. (2020) Genetic assessment of the pomological classification of plum Prunus domestica L. accessions sampled across Europe. Genetic Resources and Crop Evolution, 67 (5). pp. 1137-1161. ISSN 0925-9864 doi: https://doi.org/10.1007/s10722-02000901-y Available at https://centaur.reading.ac.uk/88861/

It is advisable to refer to the publisher's version if you intend to cite from the work. See Guidance on citing.

To link to this article DOI: http://dx.doi.org/10.1007/s10722-020-00901-y

Publisher: Springer

All outputs in CentAUR are protected by Intellectual Property Rights law, including copyright law. Copyright and IPR is retained by the creators or other copyright holders. Terms and conditions for use of this material are defined in the End User Agreement. 


\section{www.reading.ac.uk/centaur}

\section{CentAUR}

Central Archive at the University of Reading

Reading's research outputs online 


\section{Genetic Resources and Crop Evolution \\ Genetic assessment of the pomological classification of plum Prunus domestica accessions sampled across Europe \\ --Manuscript Draft--}

\begin{tabular}{|c|c|c|}
\hline Manuscript Number: & \multicolumn{2}{|l|}{ GRES-D-19-00342R2 } \\
\hline Full Title: & \multicolumn{2}{|c|}{$\begin{array}{l}\text { Genetic assessment of the pomological classification of plum Prunus domestica } \\
\text { accessions sampled across Europe }\end{array}$} \\
\hline Keywords: & \multicolumn{2}{|c|}{ DNA; genebank; Microsatellite markers; plant conservation; SSR } \\
\hline \multicolumn{3}{|l|}{$\begin{array}{l}\text { Corresponding Author Secondary } \\
\text { Information: }\end{array}$} \\
\hline Corresponding Author's Institution: & \multicolumn{2}{|l|}{ University of Sarajevo } \\
\hline \multicolumn{3}{|l|}{$\begin{array}{l}\text { Corresponding Author's Secondary } \\
\text { Institution: }\end{array}$} \\
\hline \multicolumn{3}{|l|}{ First Author Secondary Information: } \\
\hline \multirow[t]{15}{*}{ Order of Authors: } & \multicolumn{2}{|l|}{ Fuad Gasi, Ph.D. } \\
\hline & \multicolumn{2}{|l|}{ Jasna Sehic } \\
\hline & \multicolumn{2}{|l|}{ Jasmin Grahic } \\
\hline & \multicolumn{2}{|l|}{ Stein Harald Hjeltnis } \\
\hline & \multicolumn{2}{|l|}{ Matt Ordidge } \\
\hline & \multicolumn{2}{|l|}{ Daniela Benedikova } \\
\hline & \multicolumn{2}{|l|}{ Marine Blouin-Delmas } \\
\hline & \multicolumn{2}{|l|}{ Daniela Giovannini } \\
\hline & \multicolumn{2}{|l|}{ Szilvia Kovács } \\
\hline & \multicolumn{2}{|l|}{ Kersti Kahu } \\
\hline & \multicolumn{2}{|l|}{ Gunars Lacis } \\
\hline & \multicolumn{2}{|l|}{ Marc Lateur } \\
\hline & \multicolumn{2}{|l|}{ Torben Bo Toldam-Andersen } \\
\hline & \multicolumn{2}{|l|}{ Vladislav Ognjanov } \\
\hline & \multicolumn{2}{|l|}{ Hilde Nybom } \\
\hline \multicolumn{3}{|c|}{ Order of Authors Secondary Information: } \\
\hline Funding Information: & $\begin{array}{l}\text { Financial support was obtained through } \\
\text { the ECPGR Activity Grant Scheme (Phase } \\
\text { IX) First Call (PRUNDOC Project) and } \\
\text { Fifth Call (Prunus Alignment Project). }\end{array}$ & Not applicable \\
\hline Abstract: & \multicolumn{2}{|c|}{$\begin{array}{l}\text { The genotyping of European fruit tree collections has helped to identify synonyms, } \\
\text { determine parentage, reveal key specimens in the collections and provide information } \\
\text { on the development of modern cultivars from one or several progenitors. However, }\end{array}$} \\
\hline
\end{tabular}


studies on European plum Prunus domestica have been lagging behind, mainly because of the hexaploid chromosome number. In this co-operative study, 104 accessions conserved by 14 partners across Europe were phenotyped for 20 descriptors, and genotyped for 8 SSR loci together with 8 reference cultivars. Based on the descriptors as well as additional information supplied by the partners, as well as the scientific and horticultural literature, each accession was assigned to one of six pomological groups; (1) egg plums sensu lato (E), (2) prunes of the French d'Agen type (P/A), (3) prunes of the Central-Southeast European Zwetschen type (P/Z), (4) greengages (G), (5) mirabelles (M) and (6) bullaces, damsons and var. pomariorum (D/B). A MANOVA conducted on descriptor data revealed significant differentiation among the pomological groups as well as a geographic impact on the differentiation of local plum accessions in Europe. SSR data showed that two trios and seven pairs of genotypes had very similar allele profiles and possibly are genetically identical in spite of different accession names. An AMOVA indicated sparse genetic differentiation when accessions were grouped according to geographic origin whereas significant differences were obtained among pomological groups. A Bayesian analysis of genetic structure, as well as a discriminant analysis of principal components (DAPC), further revealed levels of similarity among and within the different pomological groups, suggesting that egg plums sensu lato $(E)$ and greengages $(G)$ can be referred to subsp. domestica while damsons and bullaces (D/B) but also Central-Southeast European prunes $(\mathrm{P} / \mathrm{Z})$ show more affinity to subsp. insititia. The small and possibly heterogeneous groups with mirabelles $(M)$ and prunes of the d'Agen type (P/A) take an intermediate position suggesting a hybridogenic origin.

\section{Response to Reviewers:}

\section{Dear Editor-in-Chief,}

In the following text we state all the revisions made to the manuscript in accordance to the reviewers recommendations.

Reviewer \#1:

One minor edit needed- Page 11- presumably instead of presumable

Has been changed

Reviewer \#2:

The quality of all figures, especially for Figures 3,4 and 5 , should be improved.

The quality of the figures have been improved.

Please check the magnitude of the axes in Figures 3 and 4 and re-do the figures accordingly.

The scale/magnitude, as well as the values on $\mathrm{X}$ axes in Fig. 3 and 4 are identical ( 0 to 120). Regarding the $Y$ axes, the scale in Fig. 3 and 4 is also identical: from -1.0 to 2.0 in Fig. 3 and from -2.0 to 1.0 in Fig. 4, making these graphs comparable. The differences in values on $Y$ axes between Fig. 3 and Fig. 4 are the results of differences in positioning of individual plum accessions as an outcome of the two factorial correspondence analyses (Fig. 3 - based on pomological groups and Fig. 4 -based on geographical origin). This difference is not something that was pre-set, as an option in the R software, but represents the actual result of the two analyses. Namely, although both analyses rely on the same molecular data set, the number of apriori set groups ( 7 pomological - Fig 3 and 5 geographical - Fig. 4), as required by FCA, affects the outcome of the factorial correspondence analyses as well as the graphical display of the results.

However, we did notice an error in the titles of the Fig. 3 and 4. Number of accessions was stated as 112 , but should be 106 , as it is explained in the original text of the Material and methods, relating to FCA and AMOVA. This has now been corrected in the manuscript.

Also, the quality of these two figures has been improved.

Figure 5A and Figure 5B have to be shown in the same graphical format.

This has now been done. 
Please include the headings in the first sheet of the supplementary data.

The headings on the first sheet of the supplementary data have been added!

With kind regards,

The authors

Powered by Editorial Manager ${ }^{\circledR}$ and ProduXion Manager ${ }^{\circledR}$ from Aries Systems Corporation 


\section{Genetic assessment of the pomological classification of plum Prunus domestica accessions sampled across Europe}

F. Gaši ${ }^{1}$ (0000-0002-7348-7433) J. Sehic ${ }^{2}$ (ORCID 0000-0002-4406-4431); J. Grahic ${ }^{1}$; S.H. Hjeltnes ${ }^{3}$, M. Ordidge ${ }^{4}$ (ORCID 0000-0003-0115-5218), D. Benedikova ${ }^{5}$, M. Blouin-Delmas $^{6}$, P. Drogoudi ${ }^{7}$ (ORCID: 0000-0001-9804-4543), D. Giovannini ${ }^{8}$ (ORCID 0000-0003-0977-390X), M. Höfer ${ }^{9}$, K. $\mathrm{Kahu}^{10}$, S. Kovács ${ }^{11}$, G. Lācis ${ }^{12}$ (ORCID 0000-0002-9877-8317), M. Lateur ${ }^{13}$, T.B. Toldam-Andersen ${ }^{14}$ (ORCID: 0000-0002-8602-4657), V. Ognjanov ${ }^{15}$ and H. Nybom ${ }^{2}$ (ORCID 0000-0002-4355-8106)

${ }^{1}$ Faculty of Agriculture and Food Sciences, University of Sarajevo, Sarajevo, Bosnia and Herzegovina, ${ }^{2}$ Balsgård-Department of Plant Breeding, Swedish University of Agricultural Sciences, Fjälkestadsvägen 459, SE-291914 Kristianstad, Sweden,

${ }^{3}$ Njøs næringsutvikling, Njøsavegen 5, N-6863 Leikanger, Norway,

${ }^{4}$ School of Agriculture, Policy and Development, University of Reading, Whiteknights, Reading, RG6 6AR, UK,

${ }^{5}$ National Agriculture and Food Centre, Research Institute of Plant Production, Bratislavskácesta 122, SK-921 68 Piešt'any, Slovakia,

${ }^{6}$ INRA-Unité Expérimentale Arboricole, Domaine de la Tour de Rance, F-47320 Bourran, France,

${ }^{7}$ HAO-'Demeter', Institute of Plant Breeding and Plant Genetic Resources, Department of Deciduous Fruit Trees, 59200 Naoussa, Greece,

${ }^{8}$ CREA-Research Centre for Olive, Citrus and Fruit Tree, via la Canapona 1 bis, 47121 Forlì, Italy,

${ }^{9}$ Julius Kühn-Institut (JKI), Federal Research Centre for Cultivated Plants, Institute for Breeding Research on Fruit Crops, Pillnitzer Platz 3a, D-01326 Dresden, Germany,

${ }^{10}$ Estonian University of Life Sciences, Institute of Agricultural and Environmental Sciences, Polli Horticultural Research Centre, Kreutzwaldi 1, Tartu 51014, Estonia,

${ }^{11}$ National Agricultural Research and Innovation Centre, Fruitculture Research Institute, 2 Park str., 1223 Budapest, Hungary,

${ }^{12}$ Institute of Horticulture (LatHort), Graudu 1, LV3701 Dobele, Latvia,

${ }^{13}$ CRA-W, Department of Life Sciences, Breeding \& Biodiversity Unit, Rue de Liroux 4, Bâtiment Emile Marchal, B-5030 Gembloux, Belgium,

${ }^{14}$ Department of Plant and Environmental Sciences, Copenhagen University, Højbakkegaard Alle 13, 2630 Taastrup, Denmark,

${ }^{15}$ Faculty of Agriculture, Institute for Fruit Growing \& Viticulture, Sq. Dositeja Obradovica 8, SRB21000 Novi Sad, Serbia.

\section{Abstract}

The genotyping of European fruit tree collections has helped to identify synonyms, determine parentage, reveal key specimens in the collections and provide information on the development of modern cultivars from one or several progenitors. However, studies on European plum Prunus domestica have been lagging behind, mainly because of the hexaploid chromosome number. In this co-operative study, 104 accessions conserved by 14 partners across Europe were phenotyped for 20 descriptors, and genotyped for 8 SSR loci together with 8 reference cultivars. Based on the descriptors as well as additional information supplied by the partners, as well as the scientific and horticultural literature, each accession was assigned to one of six pomological groups; (1) egg plums sensu lato (E), (2) prunes of the French d'Agen type (P/A), (3) prunes of the Central-Southeast European Zwetschen type (P/Z), (4) greengages (G), (5) mirabelles (M) and (6) bullaces, damsons and var. pomariorum (D/B). A MANOVA conducted on descriptor data revealed significant differentiation among the pomological groups as well as a 
geographic impact on the differentiation of local plum accessions in Europe. SSR data showed that two trios and seven pairs of genotypes had very similar allele profiles and possibly are genetically identical in spite of different accession names. An AMOVA indicated sparse genetic differentiation when accessions were grouped according to geographic origin whereas significant differences were obtained among pomological groups. A Bayesian analysis of genetic structure, as well as a discriminant analysis of principal components (DAPC), further revealed levels of similarity among and within the different pomological groups, suggesting that egg plums sensu lato (E) and greengages $(\mathrm{G})$ can be referred to subsp. domestica while damsons and bullaces (D/B) but also Central-Southeast European prunes (P/Z) show more affinity to subsp. insititia. The small and possibly heterogeneous groups with mirabelles (M) and prunes of the d'Agen type (P/A) take an intermediate position suggesting a hybridogenic origin.

Keywords: DNA, genebank, microsatellite markers, plant conservation, SSR

\section{Introduction}

Recently, genotypic and phenotypic characterisation of fruit tree germplasm has been undertaken in several large international projects, e.g., FruitBreedomics targeting apple and peach (Laurens et al. 2018). Genotyping efforts have identified numerous synonyms and mislabelling in European fruit tree collections (e.g. apple: Urrestarazu et al. 2016) thus enabling cost-effective management of the conserved material. Parentage has been certified, sometimes for several generations, and key individuals that hold a central position in the germplasm have been identified (e.g. apple: Ordidge et al. 2018; Muranty et al. submitted). Combining genotypic and phenotypic data for the same material can help to ensure that suitable germplasm is incorporated in modern plant breeding programs, and facilitate the identification of particular genes of interest, e.g., apple (Urrestarazu et al. 2017), peach (Micheletti et al. 2015; Aranzana et al. 2017), apricot (Bourguiba et al. 2012) and sweet cherry (Mariette et al. 2010). Additionally, association between genetic structure and geographic origin has been revealed in several fruit crops, providing information on the development of modern cultivars from one or several progenitor species and the movement of plant material along trade routes to final establishment in present-day production areas (Micheletti et al. 2015; Urrestarazu et al. 2016).

All of the previously mentioned fruit crops are primarily diploid and thus amenable to genotyping with SSR (simple sequence repeat) markers, and each crop represents a single, relatively homogenous species. By contrast, the plums grown in Europe mostly belong to the hexaploid $P$. domestica L. s.l., making genotyping with microsatellite markers a somewhat more complicated and laborious task. Prunus domestica probably originated in southeastern Europe or western Asia around the Caucasus Mountains and the Caspian Sea. Results of a recent sequence-based genotyping study agree with the generally accepted view that $P$. domestica derives from the diploid cherry plum or myrobalan (P. cerasifera Ehrh.) and possibly also the tetraploid wild species sloe or blackthorn ( $P$. spinosa L.) (Reales et al. 2010; Zhebentyayeva et al. 2019). However, the aforementioned studies indicate that a third, so far unknown Eurasian plum species could be involved. A closely related and also hexaploid species, P. insititia L., differs from common $P$. domestica by smaller and more compact trees, smaller and ovate leaves, and smaller fruits. This taxon is better treated as $P$. domestica subsp. insititia (L.) C.K. Schneider due, e.g. to the great similarities in chloroplast DNA between this taxon and P. domestica (Reales et al. 2010).

Plum cultivars are commonly divided into various pomological groups, for example (1) prunes with small to medium-sized, elliptic to oblong, usually blue to purplish fruits and relatively firm, spicy, freestone flesh that is suitable for drying (e.g. the French 'd'Ente'/'Prune d'Agen' and the central-southeast European 'Hauszwetsche'/'Bistrica'/'Požegača'/'Besztercei'), (2) egg plums with medium to large, 
ovate or elliptic fruits with rounded ends and tender, sweet flesh that often clings to the stone (e.g. the British 'Victoria'), (3) greengages with medium-sized, rounded and usually greenish fruits with tender and very sweet cling-stone flesh (e.g. the French 'Reine-Claude Verte'), (4) damsons and bullaces with small, rounded to oval fruits with bluish or yellow skin (many local cultivars as well as the commonly used rootstock 'St. Julien'), and (5) mirabelle plums with small rounded fruits with yellow to orange skin and very sweet, free-stone flesh (e.g. the French 'Mirabelle de Nancy').

The pomological groups are reflected by a subspecific taxonomical classification; prunes are usually referred to as $P$. domestica subsp. domestica, and egg plums to either the same subspecies or sometimes to $P$. domestica subsp. intermedia Röder, while damsons, bullaces and 'St. Julien' plums are classified as $P$. domestica subsp. insititia. The mirabelles are treated as a subspecies of their own, subsp. syriaca (Borkh.) Janchen ex Mansfeld, or as the variety syriaca within subsp. insititia (Halapija Kazija et al. 2014). Similarly, the greengages have been described as a subspecies, $P$. domestica subsp. italica (Borkh.) Gams, or as the variety italica within subsp. insititia. Greengages have, however, also been regarded as hybrids between subsp. domestica and the mirabelles due to similarities with mirabelles in fruit morphology and taste (Hedrick 1911). Classification has varied over time for other groups with small and rounded fruits, like the French perdrigons (e.g. 'Perdrigon Violette') and the yellow-fruited landraces in var. pomariorum (Boutigny) Dostál (e.g. the German 'Spilling').

European plum, a term that commonly encompasses most if not all of the previously described groups, is a rather heterogeneous crop. However, there are relatively few molecular marker-aided studies on the genetic diversity of this crop, probably because of difficulties in scoring SSR loci in hexaploids. Genotyping projects carried out in Croatia and other European countries (Halapija Kazija et al. 2014), France (Horvath et al. 2011), Greece (Athanasiadis et al. 2013; Merkouropoulos et al. 2017), Hungary (Makovics-Zsohár 2017), Scandinavia (Sehic et al. 2015) and Spain (Urrestarazu et al. 2018) have shown that local cultivars often differ considerably from widespread international cultivars. However, the question of whether there is a true geographic component to the genetic variation, or whether the differentiation between widespread and local cultivars is mainly an effect of biased sampling of the subspecies/pomological groups, has not been fully resolved.

The European Cooperative Programme for Plant Genetic Resources (ECPGR, http://www.ecpgr.cgiar.org/) is aimed at ensuring long-term conservation of important germplasm in Europe as well as facilitating an increased utilization of this germplasm, e.g. in plant breeding. Special attention is given to the selection of unique accessions with valuable traits, of European origin or importance to Europe, in order to establish decentralized European Collections under the rules of AEGIS (A European Genebank Integrated System_http://www.ecpgr.cgiar.org/aegis/). The ECPGR Prunus workgroup carried out two projects, 'PRUNDOC' and 'Prunus Alignment', in 2015 and 2018 respectively, both funded by Bioversity International. During PRUNDOC, a number of descriptors for describing and discriminating plum ( $P$. domestica L. s.l.) accessions, were selected from lists available in the literature in order to harmonize characterization and evaluation of accessions across collections (Hjeltnes et al. 2017). Within the two projects, morphological and evaluation data on local plum accessions, conserved in 14 different European countries, was collected based on the PRUNDOC descriptor list.

This study aims to quantify the genetic variation and determine the impact of pomological/taxonomical classification and geographic origin on the genetic differentiation among a representative set of plum accessions maintained in Europe. For this purpose, 104 accessions conserved and phenotyped by partners in the 'PRUNDOC' and 'Prunus Alignment' projects, were classified into pomological groups and genotyped using eight SSR primer pairs.

\section{Material and methods}




\section{Plant material}

A total of 104 local plum accessions were analysed in this study (Table 1). Each of the 14 partners, from Great Britain in the West to Estonia and Latvia in the East and from Norway and Sweden in the North to Italy and Greece in the South, contributed plant material and phenotyping data for 4-18 accessions that are presently conserved by the project partners. Eight previously used reference cultivars, 'Bistrica', 'Čačanska Rodna', 'Hanita', 'Mirabelle de Nancy', 'Reine-Claude Violette', 'Stanley', 'Topfirst' and 'Valor', were included to enable comparison with the data set of Sehic et al. (2015).

\section{Phenotyping and classification}

All accessions were scored for 20 descriptors by each partner using trees and fruit in their own collections (Table 2). Based on the descriptors as well as additional information supplied by the partners and available scientific and horticultural literature, each accession was assigned to one of six pomological groups; (1) egg plums sensu lato (E), (2) prunes of the French d'Agen type (P/A), (3) prunes of the Central-Southeast European Zwetschen type (P/Z), (4) greengages (G), (5) mirabelles (M) and (6) bullaces, damsons and var. pomariorum (D/B). Differentiation between the two prune types is not clearcut but P/A are described as having more pointed ends on both fruits and stones. In addition, egg plums were divided into two groups based on average fruit size; above $40 \mathrm{~g}$ (Eb) or below (Es). The subdivision of two pomological groups (prunes and egg plums) into four new groups (P/A, P/Z, Eb and Es) was done in order to investigate if observed pomological differences had a genetic basis. In several previous papers, the term 'European plum' was applied to most cultivars that could not be referred to as greengages, mirabelles or damsons/bullaces (Horvath et al. 2011; Halapija Kazija et al. 2014; Sehic et al. 2015). 'European plum' is, however, also used to distinguish $P$. domestica as opposed to e.g. Asian plum $P$. salicina Lindl., and should therefore be avoided for assignment of pomological groups within the species.

\section{SSR analyses}

Young branches were collected in early spring from a single tree for each of the investigated accessions, and sent to Balsgård, SLU in Sweden, where they were forced indoors until leaves could be harvested. DNA was extracted from frozen leaf material using the Qiagen DNeasyTM Plant Mini Kit (Qiagen AB) according to manufacturer's instructions. A set of 8 previously published SSR primer pairs, which have already been used for a genetic study on plum (Sehic et al. 2015) (Table 3) was employed for the analyses. For DNA sequences, references, amplification procedures and annealing temperatures, see Sehic et al. (2015) with the minor change that Taq DNA polymerase (recombinant) (Thermo Fischer Scientific) was used. Diluted PCR products were mixed with Hi-Di formamide (Applied Biosystems) and an in-house prepared size standard, after which the amplified fragments were separated on an ABI 3130xl Genetic Analyser (Applied Biosystems). Software package Gene-Marker v. 1.85 (SoftGenetics LLC) was used for scoring of DNA fragments. In case of any uncertainty regarding the scoring process, PCR amplification was repeated. Multilocus SSR profiles were scored as 'allelic phenotypes' based on the presence of alleles but not their frequencies.

\section{Evaluation of phenotypic data}

Based on all 20 descriptors, relationships among the 104 local plum accessions were examined using a Factorial Analysis of Mixed Data (FAMD) (Pagès 2014), which enabled the analysis of data sets containing both quantitative and qualitative variables. The FAMD analysis was carried out in R package "FactoMineR" v. 2.41, function "FAMD" (Le et al. 2008). The distances matrix obtained through FAMD was used in order to construct a dendrogram using R package "factoextra" v. 1.0.5, function "fviz_dend" (Kassambara and Mundt 2017). A dendrogram was used instead of the default options because it provided a simpler overview of the relationships among analysed accessions. 
Geographic as well as pomological differentiation of the phenotyped plum accessions was investigated with a multivariate analysis of variance (MANOVA), performed in R v. 3.5.1, function "manova". Two presumably diploid accessions were removed from the data set, resulting in 102 accessions. The accessions were a priori divided into groups depending on (a) presumed geographic origin within one of five areas in Europe: Central, Eastern, Northeastern, Northern and Western, or (b) assigned to one of seven pomological groups (Eb, Es, G, M, P/A, P/Z and D/B).

\section{Evaluation of molecular data}

Genetic variation in the plant material was estimated with SSR allele phenotypes, and gene diversity (average expected heterozygosity, Nei 1978) was calculated across all 112 accessions using population genetics software SPAGeDI 1.3 (Hardy and Vekemans 2002). Similarity among putatively identical genotypes was quantified as the fraction of shared bands $S$, i.e. number of common bands divided by the number of bands exhibited by genotypes $\mathrm{x}$ and $\mathrm{y}: S_{\mathrm{xy}}=2 \mathrm{n}_{\mathrm{xy}} /\left(\mathrm{n}_{\mathrm{x}}+\mathrm{n}_{\mathrm{y}}\right)$.

Similarity among all 112 accessions was estimated with an Unweighted Pair Group Method with Arithmetic mean (UPGMA) cluster analysis based on a matrix with pairwise comparisons using Jaccard's similarity coefficient. Calculations were carried out with NTSYSpc v. 2.1 (Rohlf 2000) and the dendrogram was constructed in MEGA 6 software (Molecular Evolutionary Genetics Analysis) (Tamura et al. 2013).

Differentiation of accessions depending on (a) geographic origin (defined as for the phenotypic data analysis described above) and (b) assignment to pomological groups (as above), was investigated with Analyses of Molecular Variance (AMOVA) (Excoffier et al. 1992), based on the stepwise mutation model (Ohta and Kimura 1973) and performed using GenoType software [GenoType/GenoDive package (Meirmans and Van Tienderen 2004)] with 1,000 permutations.

In order to further analyse the differentiation and relationships among the pomological and geographical groups, the multivariate factorial correspondence analysis (FCA), based on a matrix of binary microsatellite allele presence/absence data, was performed using the "dudi.coa" routine in R 3.5.1 (R Core Team 2018) as suggested by Muller and McCusker (2009). The graphical display of the FCA results was done using the scatterplot3d (2D option is presented for simplicity of viewing) package v. 0.3-41 (Ligges and Mächler 2003) in the same statistical software. Four apparently synonymous accessions were removed from the data set, as well as two diploids (Danish 'Gul Havreblomme' and Slovakian $P$. cerasifera selection 63 MY BO 1), resulting in 106 accessions for AMOVA and FCA.

The Bayesian model-based cluster procedure within Structure v. 2.2.3 (Pritchard et al. 2000) was used to determine genetic structure within the set of 112 accessions. For individuals with less than six allelic variants per locus, absent allele(s) was assigned as missing data (-9). $K$ (unknown) RPPs (reconstructed panmictic populations) were computed on individuals, testing $K$ (log-likelihood) $=1-10$ for all accessions assuming that sampled cultivars were from unknown origin. Ten independent runs were conducted for each $K$. A burn-in period of 200,000 and 500,000 iterations was applied. Structure Harvester v. 0.6.1 (Earl and von Holdt 2011), which implements the Evanno method (Evanno et al. 2005), was used to estimate $K$ values for the analysed data. After determination of the most probable $K$ values, runs with maximum likelihood were used to assign individuals to specific clusters (Vigouroux et al. 2008). The assignment of a cultivar to an RPP was provided by the probability of membership $q I$ chosen at $80 \%$ according to corresponding studies on plums (Urrestarazu et al. 2018). All input files were compiled using MADC v. 1.2 (Grahic and Grahic 2017). Additionally, we conducted a discriminant analysis of principal components (DAPC) using the package adegenet 2.0.0 (Jombart et al. 2010) in R software (R Core Team 2018). Two clusters were selected according to the Bayesian information criterion (BIC).

\section{Comparison of phenotypic and molecular data}


A positive correlation between phenotypic and molecular data was investigated with a Mantel test (Mantel 1967) with 10,000 permutations, using a Gower distance matrix (phenotyping data) (Gower 1971) calculated in R package "Cluster" v. 2.0.7-1, function "daisy" (Maechler et al. 2018) and a Jaccard's distance matrix (molecular data). The test was conducted in R package "ade4" v. 1.7.13, function "mantel.rtest" (Dray and Dufour 2007).

\section{Results}

\section{Classification of accessions}

Out of the 112 accessions (Table 1), a total of 44 were classified as egg plums sensu lato (E) including three accessions reported to derive from crosses between egg plums and prunes; the Estonian 'Ave'

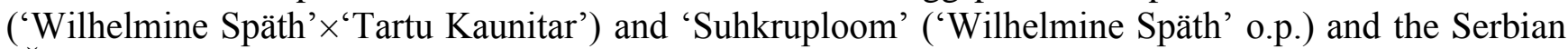
'Čačanska Lepotica' ('Stanley' $\times$ 'Ruth Gerstetter', according to Decroocq et al. (2004)). Additionally, the 44 egg plums were subdivided into two groups based on their average fruit weight (above or below $40 \mathrm{~g}$ ), with each group consisting of 22 accessions.

Fifteen accessions were classified as greengages $(\mathrm{G})$, including five with 'Reine-Claude' in the name, two that were previously described as synonymous with well-known greengages, Danish 'Kongeblomme' ('Reine-Claude van Mons' but fruit more similar to 'Prune Pêche', Henk Woldring pers. comm.) and Norwegian 'Helgøyplomme' ('Reine-Claude d'Oullins') and the documented Swedish greengage offspring 'Ive' and 'Opal'. Six accessions, only occasionally referred to as greengages, were also included: French 'Abricotée Jaune' and 'Prune de Vars', Italian 'Prunella', Swedish 'Hackman', Greek 'Mpardaki Circular' and finally 'Tarka Perdrigon', which is conserved by the Hungarian partner but probably derives from France (synonyms 'Bunter Perdrigon' and 'Perdrigon Bariolé').

The mirabelle group (M) contained three French accessions although 'Mirabelle de Flotow' deviates by having stones that are more similar to subsp. insititia (Henk Woldring pers. comm.). Three additional accessions were included: Belgian 'Prune de Prince', Danish 'Gul Rosinblomme' (which may be synonymous with 'Herrenhauser Mirabelle', Henk Woldring pers. comm.), and 'Praousti', defined as a mirabelle in the Greek collection but with larger fruit (26-40 g) than other mirabelle accessions.

Prunes were split into two groups; the French d'Agen prunes (P/A) and the Central-Southeast European Zwetschen (P/Z). In this study, French accessions 'd'Ente Double' and 'Double Robe', Italian 'Agostana', Greek 'Glyka Skopelou' (reported to be a sport of 'd'Ente' but does not have the characteristic pointed ends), and American reference cultivar 'Stanley' (cross between 'd'Ente' and British egg plum 'Grand Duke') were referred to $\mathrm{P} / \mathrm{A}$. Thirteen accessions were classified as $\mathrm{P} / \mathrm{Z}$ including Serbian reference cultivar 'Čačanska Rodna', which originated in a cross between 'Stanley' and 'Požegača' (P/Z). All P/A accessions were dark blue to purple and had medium-sized to large fruit (26-60 g) whereas P/Z accessions were blue, black or reddish and most of them had smaller fruit. Four $\mathrm{P} / \mathrm{Z}$ accessions had intermediate sized fruit (26-40 g): 'Čačanska Rodna', Belgian 'Altesse Dorée' and 'Sainte-Catherine' (which has stones more similar to P/A, Henk Woldring pers. comm.), and Slovakian 'Kozlienka'. Danish 'Gul Sveskeblomme' deviates by its yellow fruit colour and may be synonymous with 'Hartwiss Gelbe Zwetsche' (Henk Woldring pers. comm.).

Twenty-eight accessions were classified as damsons, bullaces or var. pomariorum (D/B), all of which are usually treated as subsp. insititia. Three of these, Danish 'Gul Havreblomme' (which to some extent also resembles a greengage but had a maximum of only two alleles/locus, see below) and Greek 'Ksina Skopelou' and 'Mpardaki Elliptic' had fruit that weighed over $25 \mathrm{~g}$ while the other accessions had smaller fruit.

Finally, the data set also contained the Slovakian P. cerasifera selection 63 MY BO 1. 


\section{Phenotype-based relationships}

Relationships among accessions were assessed using a factorial analysis (FAMD) with data from the 20 descriptors. Based on the matrix obtained, all 104 local plum accessions were placed into a dendrogram (Fig. 1). The accessions were first split into two main clusters, A ('Abricotée Jaune'-'d'Ente Double') and B ('Briquetch'-'Paradisu'). These were each split into two subclusters, A1 ('Abricotée Jaune''Zemgale') and A2 ('Gräfin Cosel'-'d'Ente Double'), and B1 ('Briquetch'-'Haferpflaume') and B2 ('Tarka Perdrigon'-'Paradisu'). Subcluster A1 contained 28 accessions representing all sampled plant collections except those in Italy and Slovakia. Representation of pomological groups was, however, heavily skewed towards egg plums (11) and greengages (9). In subcluster A2, all collections except those in Italy and Slovakia were again represented among the 37 accessions, with 21 egg plums and 3 greengages. Clusters B1 and B2 instead had a substantial representation of damsons/bullaces (D/B): 11 out of 25 (B1) and 7 out of 14 (B2). In B1, one small subcluster contained all the 4 Slovakian accessions (two D/B, one $\mathrm{P} / \mathrm{Z}$ and one $P$. cerasifera) while another small subcluster contained 5 French $\mathrm{D} / \mathrm{B}$ accessions together with the German 'Bühler Frühzwetsche'. The geographic influence was even larger in B2, with 13 out of 14 accessions from Italy (mostly D/B but also two egg plums, one P/A and one greengage).

\section{Phenotype-based differentiation}

Two MANOVAs were used to assess the differentiation (1) among accessions with different geographic origins, and (2) among accessions assigned to different pomological groups. The first analysis revealed a highly significant, $P<0.001$, effect of geographic origin (different, known or presumed origin of the cultivar was used instead of origin of the sample) when the 102 local accessions (excluding two diploids) were divided into 5 groups of countries; North (11 accessions from Denmark, Norway and Sweden), North-East (14 accessions from Estonia and Latvia), West (38 accessions from Belgium, France and Great Britain, Central (22 accessions from Germany and Italy) and East (17 accessions from the Czech Republic, Greece, Hungary, Serbia and Slovakia).

Differentiation among pomological groups was similarly investigated, with the 102 accessions grouped as large-fruited egg plums (21), small-fruited egg plums (20), greengages (14), mirabelles (5), French prunes (P/A; 4), Central-Southeast European prunes (P/Z; 11), and damsons/bullaces (27). Again, a highly significant differentiation was revealed $(P<0.001)$.

\section{SSR polymorphism and gene diversity}

Eight primer pairs amplified 234 distinct alleles in this study, or on average 29.3 alleles per locus (Table 3 ). Number of alleles differed considerably between loci, with only 17 detected for locus BPPCT 40 while 47 were detected for locus BPPCT 014. By contrast, gene diversity as calculated according to Nei (1978) was more similar, ranging from 0.878 to 0.934 for the same two loci, and an overall average of 0.911. SSR polymorphism and gene diversity were determined for $\mathrm{K}=2$ reconstructed panmictic populations (RPPs), as well as a group with admixed accessions (Table 3) assigned through Bayesian structure analysis. Number of distinct alleles was the lowest within the largest group (RPP1, 49 samples) with 17 alleles per locus on average and a gene diversity of 0.889 . Highest value for alleles per locus, 24.38, was noted for RRP2 (43 samples) while both RPP2 and the admixed accessions (20 samples) possessed high gene diversity (0.912 and 0.913, respectively).

DNA-based evaluation of hexaploid plum accessions is considerably more difficult than for diploid genotypes since up to six alleles may occur in each locus, but the number scored is usually somewhat lower. Overlooking a present but faint band is thus possible as well as mistakenly scoring an artefactual band as an allele. All but four accessions produced up to five ( 23 accessions) or six ( 85 accessions) alleles per locus in keeping with their presumed hexaploidy. Two accessions produced a maximum of four alleles per locus, Greek 'Asvestochoriou' and Latvian 'Latvijas Sarkanā Olplūme, but are most likely 
also hexaploid. In addition, the diploid $P$. cerasifera had, as expected, only one or two alleles in all loci except for UDP 96 where a third, most likely artefactual band was scored. More surprising, 'Gul Havreblomme' exhibited only one or two alleles in every locus. Whether this cultivar is truly a diploid, needs to be investigated further e.g. using flow cytometry.

\section{Molecular marker-based similarities}

Results of a DNA-based UPGMA cluster analysis including all 104 local plum accessions and 8 reference cultivars, are shown in a dendrogram (Fig. 2). Axes differentiating the major clusters were very short and discrimination therefore unclear. The analysis did, however, reveal several cases of highly similar or even identical accessions. The two slightly morphologically divergent accessions of French damson cultivar 'Prune de Chien' had 33 completely identical alleles and are treated as genetically identical in this study.

Three greengages also appear to be close to identical although sampled in different collections under different names; the Greek 'Mpardaki Circular', the Norwegian 'Helgøyplomme' and the Belgian 'Reine-Claude Souffriau' which is reported to originate from an orchard with 'Reine-Claude Verte'. They shared 28, 31 and 32 alleles, respectively, and the minor differences (either 2-bp differences in allele size, or the occurrence of additional alleles) are most likely caused by mutations or experimental artefacts. 'Helgøyplomme' is usually regarded as a sport of 'Reine-Claude d'Oullins', which was substantiated by comparison with a previously analysed sample of 'Reine-Claude d'Oullins' in our data base (from the study of Sehic et al. 2015). The fraction of shared bands, $S$, varied between 0.89 and 0.94 for all pairwise comparisons among 'Mpardaki Circular', 'Helgøyplomme', 'Reine-Claude Souffriau' and 'Reine-Claude d'Oullins'. Whether the two Reine-Claude cultivars are truly clonal or if one of the sampled trees may have been mislabeled, is presently not known. It should also be noted that none of the analysed greengages appears to be synonymous with 'Reine-Claude Verte' since they differed clearly $(S<0.80)$ when compared to a sample of this cultivar in our database.

Another case involved three $\mathrm{P} / \mathrm{Z}$ accessions representing an old and well-known type of prune, which has been widely grown in Central and Southeastern Europe for use in desserts and liquors: Hungarian 'Besztercei 5/a', Serbian 'Požegača' and Croatian 'Bistrica' (the latter used as a reference cultivar). 'Besztercei 5/a' and 'Bistrica' were identical in 28 out of 30 alleles $(S=0.97)$, while both of them shared 27 out of 31 alleles $(S=0.93)$ with 'Požegača'. Very restricted variation in SSR profiles among 'Požegača'/'Bistrica' accessions has been reported previously by Halapija-Kazija et al. (2013), who speculated that this could be due to its potential status as a landrace cultivar. A fourth accession, 'Tölcsér Koronájú' from Hungary, was similar but differed at several loci (25 alleles out of 34 were identical with 'Besztercei', $S=0.85$ ) and may instead be a close relative, e.g. a seedling offspring.

Several additional cases of very similar and potentially identical genotypes were encountered. P/A prunes 'd'Ente Double' and 'Double Robe' shared 28 out of 35 alleles $(S=0.89)$. By contrast, Greek 'Glyka Skopelou' which has been described as a sport of 'd'Ente', shared only 19 out of 50 alleles $(S=0.55)$ with 'd'Ente Double' and 15 out of $44(S=0.51)$ with 'Double Robe' thus being clearly different. Italian greengage 'Prunella' shared 28 out of 36 alleles $(S=0.88)$ with the reference cultivar 'ReineClaude Violette', which it also resembles in its rounded green fruits with a violet over colour. Relatively similar but genetically different genotypes were noted also for two other greengages: Danish 'Kongeblomme' and Hungarian 'Tarka Perdrigon', $S=0.78$. Finally, several cases of relatively high similarity involved D/B accessions; 'Ramassin Ramassin' and 'Ramassin di Pagno' from Italy with very small purple fruit, $S=0.86$, 'Cariadoggia' and 'Muninca' also from Italy but with slightly larger and yellow fruit, $S=0.84$, and 'Spilling' from Germany and 'Eikerplomme' from Norway, both with small yellow-orange fruit of the var. pomariorum type, $S=0.80$.

\section{Molecular marker-based differentiation}


A possible differentiation linked to geographic origin was investigated for 106 accessions (including reference cultivars but excluding 4 synonymous accessions and two diploids) applying AMOVA among 5 groups; North (11 accessions), North-East (14), West (40, including the American reference 'Stanley' and the Canadian reference 'Valor' with parents from Great Britain and France), Central (24) and East (17). The AMOVA results showed that only $0.7 \%$ of the total variation occurred between geographically defined groups, suggesting that very little of the genetic differentiation among local plum cultivars in Europe is associated with their immediate geographic origin.

Differentiation between pomological groups, when the 106 accessions were divided into large-fruited egg plums (22), small-fruited egg plums (22), greengages (14), mirabelles (6), French prunes (P/A, 5), Central-Southeast European prunes (P/Z, 11) and damsons/bullaces (26), explained a small (1.6\%) but statistically significant $(\mathrm{P}<0.001)$ portion of the total variation.

Relationships between the 7 pomological groups were further investigated with an FCA (Fig. 3). In a two-dimensional plot, small-fruited egg plums and greengages were placed side-by-side with the largefruited egg plums found in the lower left-hand corner (Fig. 3). On the right-hand side, P/A and P/Z prunes appeared close together but still with a degree of separation. Mirabelles and damsons/bullaces have a more central position but are closer to the prunes than to the egg plums and greengages. In an FCA of the 5 geographic groups, there was considerable overlap although the two largest groups, Central and Western, appeared on opposite sides in the 2-dimensional plot (Fig. 4).

\section{Genetic structuring and DAPC}

$\Delta K$ analyses (Evanno et al. 2005) revealed a maximum value for $K=2$ and two smaller peaks for $K=6$ and $K=8$ (Fig. 5a). Bayesian structure analyses were carried out on 104 local cultivars and 8 reference cultivars (Fig. 6). The two RPPs inferred for $K=2$ contained 49 and 43 accessions respectively, that were assigned with a probability of membership $q I>80 \%$ (Table 1). RPP2:1 was dominated by egg plums (32 accessions) and greengages (13), but 3 P/A prunes were also included, 'd'Ente Double', 'Double Robe' and 'Stanley', as well as Italian 'Lazzarinu' classified as a damson (D/B). By contrast, RPP2:2 contained 24 accessions classified as D/B and $10 \mathrm{P} / Z$ prunes. In addition, one mirabelle ('Praousti'), one greengage ('Prune de Vars'), and 6 egg plums (French 'Verdanne', Hungarian 'Duránci', Italian 'Paradisu', Latvian 'Kārsavas', and Greek 'Avgata Skopelou' and 'Asvestochoriou') were allocated to RPP2:2. All but the last of these egg plums, do, however, have fruit below 40 grams (belonging to the Es pomological group). Finally, the $P$. cerasifera accession as well as another putative diploid, 'Gul Havreblomme', were also included in this RPP. Provided that egg plums, greengages and possibly also some of the P/A prunes belong to subsp. domestica, while damsons/bullaces and $\mathrm{P} / \mathrm{Z}$ prunes have a stronger affinity to subsp. insititia, differentiation between the two RPPs appears to be associated with interspecific taxonomy. The 20 admixed cultivars (assigned to RPP1 or RPP2 with 80\%>qI>50\%) included 5 mirabelles, 6 egg plums (all with fruits below 40 grams), one greengage, 2 P/A prunes, $3 \mathrm{P} / \mathrm{Z}$ prunes and $3 \mathrm{D} / \mathrm{B}$.

RPP2:1 (from $K=2$ ) was divided into two groups when $K=6 ; 13$ accessions in RPP6:1 (7 egg plums and 6 greengages) and 12 in RPP6:2 (4 egg plums, 6 greengages and 2 P/A prunes) (Table 1). In addition, there were two smaller groups; RPP6:3 with three accessions: egg plum 'Latvijas Dzeltenā Olplūme' and the very similar D/B accessions 'Eikerplomme' and 'Spilling', and RPP6:4 with the three almost identical P/Z accessions 'Besztercei', 'Bistrica' and 'Požegača' together with very similar 'Tölscér Koronájú'. Evaluation of additional accessions that displayed probability of membership above $50 \%$ with one of the RPP6 groups, supported the conclusion that RPP6:1 and RPP6:2 were made up mainly of subsp. domestica accessions but with no further differentiation associated to pomological group, whereas RPP6:4 contained a group of synonymous or closely related P/Z accessions. Interestingly several other

$\mathrm{P} / Z$ accessions (the 'Požegača'-offspring 'Čačanska Rodna' together with 'Altesse Dorée', 'Bühler Frühzwetsche', 'Ersinger Frühzwetsche' and 'Sainte-Catherine') showed more than $50 \%$ affiliation with RPP6:4, as did also German 'Haferpflaume' (D/B). Accessions with more than 50\% affiliation to RPP6:3 
include both egg plums and damsons/bullaces, mostly from northern or northeastern Europe. Numerous accessions contained a substantial influence of two additional genomic groups (RPP6:5 and RPP6:6), but none of the accessions could be assigned with $50 \%$ probability to either one of them.

For $K=8$, most of the accessions appeared to be admixed and only three groups had any accessions assigned with at least $80 \%$ probability; RPP8:1 contained 12 of the 13 accessions from RPP6:1, RPP8:7 contained 5 of the 12 accessions in RPP6:2, while RPP8:3 contained the same four accessions as RPP6:4. Considering the weak $\Delta K$ signals for $\mathrm{K}=6$ and $\mathrm{K}=8$ (Fig. 5a), as well as a high proportion of admixed genotypes (Fig. 6a, b and c), results obtained for these $K$ values must be treated with great caution since the suggested population structure cannot be resolved properly until more data becomes available. Instead, the results of the $\mathrm{K}=2$ as well as the FCA, formed the basis for the discussion and conclusions in this study.

Using the Bayesian information criterion (BIC) (Fig. 5b), a population structure with two groups was indicated for the discriminant analysis of principal components (DAPC) (Fig. 6d). Assignment of the 112 genotypes into two clusters (DAPC lacks the category admixed) was very similar to the results of the Bayesian Structure analysis for $\mathrm{K}=2$. The only substantial difference between the results of the Bayesian Structure analysis $(\mathrm{K}=2)$ and DAPC, was the Italian accession 'Sanacore' which belonged to RPP2:1 in the first analysis and to the second cluster in the latter analysis (Table 1). All other, somewhat divergent results concerned accessions that were admixed in the Structure analysis (probability of membership lower than $80 \%$, to either RPP for $\mathrm{K}=2$ ).

\section{Correlation between genetic and phenotypic data sets}

A Mantel test, performed to determine the correlation between the descriptor-based data and the SSR marker data, showed a relatively low correlation $(\mathrm{R}=0.1693)$ which was nonetheless statistically significant $(\mathrm{P}<0.0001)$.

\section{Discussion}

\section{Phenotyping}

A total of 20 standardized descriptors were used, and methods for measuring and scoring were carefully defined to avoid unnecessary bias. Nevertheless, one must take into consideration that the collected data might have been influenced by environmental factors (the accessions being grown in different countries), and through subjectivity of persons undertaking the scoring. We noted substantial phenotypic differences for some accessions that had identical or nearly identical SSR profiles. Some of this variation may, however, be attributable to mutations and the selection of 'sports'. For example, even when grown and scored in one place, morphological variation was previously noted among clones of 'Reine-Claude Verte' despite their identical SSR profiles (Gharbi et al. 2014). Many 'colour sports' are well known to exist in other fruit crops.

The MANOVA used for differentiating between 7 pomological groups was highly significant, and the phenotype-based FAMD (Fig. 1) revealed a crude differentiation between, on the one hand, egg plums, greengages and P/A prunes and, on the other hand, P/Z prunes and damsons/bullaces. A similar level of differentiation was obtained when the material was grouped into 5 geographic areas of origin. The FAMD-based dendrogram indicated particularly strong grouping among accessions from Italy, and from Slovakia.

Since representation of pomological groups varied in the samples from different countries, it is difficult to disentangle the influence of pomological grouping from that of geographic origin. Northern (Denmark, Norway and Sweden) and Western (Belgium, France and Great Britain) material had a mixed representation among the different pomological groups, whereas the 14 accessions sampled in collections 
of Estonia and Latvia (group North-East) were all egg plums. Accessions originating in Germany or Italy (group Central) instead included 10 accessions classified as D/B, two each of $\mathrm{P} / \mathrm{Z}$ and greengages, one P/A, and only six egg plums. Similarly, a considerable number of D/B (8) and P/Z (5) but only 4 egg plums originated from countries in the Eastern group (Greece, Hungary, Serbia and Slovakia). To what extent these differences reflect the genetic structure of plum germplasm in Europe is difficult to say. Policies for collecting and maintaining plant material in national fruit tree collections differ considerably among countries (Nybom and Garkava-Gustavsson 2009).

\section{Molecular data}

The mean number of alleles per locus was 29.3, which is higher than in most previous studies: 18.7 alleles in 62 traditional Croatian, regional and international accessions (Halapija Kazija et al. 2014), 19.3 alleles in 55 mostly Hungarian accessions (Makovics-Zsohár et al. 2017), 20.0 alleles in 45 European plum accessions preserved in Germany (Xuan et al. 2011), 22.7 alleles in 76 traditional Nordic and international accessions (Sehic et al. 2015), 23.4 alleles in 166 Spanish and international accessions (Urrestarazu et al. 2018) and 29.0 in 80 accessions from the French National Collection (Horvath et al. 2011). It is possible that the reason for this, and the reason for the closest similarity to the study by Horvath et al. (2011), is the broad representation of different pomological groups in our samples.

In our study, the highest number of different alleles was detected for BPPCT 014, and the lowest for BPPCT 040, which is similar to the study by Sehic et al. (2015). Gene diversity calculated for all analysed samples (0.911) is almost identical to the values reported by Halapija Kazija et al. (2014) and Sehic et al. (2015).

The most interesting results regarding number of different alleles and gene diversity, were noted when we compared accessions with a probability of membership $q I>80 \%$ to RPP2:1 and RPP2:2 in Bayesian structure analysis for $\mathrm{K}=2$. Contrary to expectations, the largest RPP (RPP2:1), consisting of 49 accessions, had the lowest values for these parameters. Higher values for both mean number of alleles and gene diversity were detected for accessions assigned to RPP2:2 ( $n=43)$. Even the admixed group of accessions $(\mathrm{n}=20)$ possessed a higher number of distinct alleles and gene diversity comparable to RPP2:1. The homogeneity found within RPP1:2 is a likely consequence of the fact that this group includes numerous cultivars derived from modern breeding programs involving mainly subsp. domestica. By contrast, RPP2:2, which consists mainly of old local accessions belonging to the more primitive subsp. insititia, is notably more diverse. Similar logic can be applied for the admixed accessions, which presumably represent the results of hybridization between the various plum groups or subgroups and thus in spite of their low number $(\mathrm{n}=20)$ possess significant diversity.

Neither Horvath et al. (2011) nor Halapija Kazija et al. (2014) found any correlation between the majority of scored morphological traits and the molecular data. However, in this study a low but significant correlation was found between the data sets. This is probably due to inclusion of a number of phenotypic descriptors which are effective in classifying plum accessions into various pomological groups, among which different levels of genetic differentiation were detected using molecular data. Also, similar patterns of separation of e.g. egg plums and greengages on one side and damsons/bullaces and $\mathrm{P} / \mathrm{Z}$ prunes on the other side, were noticeable in both the FAMD-based dendrogram (using phenotypic data) and in the FCA (using molecular data).

\section{Differentiation of plum cultivars}

Although accessions of subsp. insititia show more primitive features (smaller trees, smaller and often more sour fruits) than accessions of subsp. domestica generally do, validated wild forms have never been located for either taxon (Reales et al. 2010; Zhebentyayeva et al. 2019). Moreover, the very similar chloroplast haplotypes reported in studies of a wide variety of accessions from both subspecies (Reales et al. 2010; Horvath et al. 2012; Urrestarazu et al. 2018) suggest that they originate from the same 
ancestral line but have become increasingly dissimilar due to differences in exposure to domestication, including active selection for genotypes with traits that could be perpetuated through centuries by vegetative propagation (Woldring 2000; Zhebentyayeva et al. 2019).

Division of plum germplasm between the two taxa is handled very differently in different studies. In some previous multivariate and/or SSR-based studies on plum diversity, almost all accessions were classified as $P$. domestica and only a few to $P$. insititia or subsp. insititia (Milošević and Milošević 2012). In another study, mirabelles as well as damsons were treated as P. insititia (Halapija Kazija et al. 2014). In yet another, mirabelles, greengages and Quetche/Zwetschen (termed 'damsons'), were all treated as subsp. insititia (Horvath et al. 2011) whereas several small-fruited cultivars were treated as 'European plum' including some accessions classified as damsons/bullaces (D/B) in our study.

Several SSR-based studies have focused on the comparison of local plum germplasm to sets of international reference cultivars (Horvath et al. 2011; Halapija Kazija et al. 2014; Sehic et al. 2015; Merkouropoulos et al. 2016; Makovics-Zsohár et al. 2017; Urestarrazu et al. 2018). Not surprisingly, a major division was found between local germplasm belonging mainly to subsp. insititia, and international cultivars belonging mainly to subsp. domestica (egg plums sensu lato) (Halapija Kazija et al. 2014; Sehic et al. 2015). Two groupings of Hungarian germplasm, Zwetsche and subsp. insititia, were distinguished from a third group with international reference cultivars (egg plums sensu lato, greengages and P/A prunes) in a Bayesian structure analysis by Makovics-Zsohár et al. (2017). In a study comparing Spanish germplasm with international reference cultivars, a grouping with greengages was the first to split off at $K=2$, while the remaining accessions divided into two subgroups at higher $K$ values; one containing local Spanish cultivars together with old Spanish and French reference cultivars, and another more heterogeneous subgroup containing the majority of reference cultivars including several P/A and P/Z accessions (Urrestarazu et al. 2018).

In the study most similar to ours, in terms of sample range, Horvath et al. (2011) analysed a total of 80 accessions in France. Eighteen of these were included in our study although we found virtually no overlap in the structuring of accessions in the two studies. Both RPP2:1 and RPP2:2 for $K=2$ by Horvath et al. (2011), contained accessions that were found to differ widely in our study where they were classified as egg plums and D/B, with the addition of P/A and P/Z prunes in RPP2:1, and one mirabelle and one greengage in RPP2:2. Five additional greengages were admixed. For $K=4$ similar groups were obtained by Horvath et al. (2011), except that RPP4:3 now contained the mirabelle, two greengages and one $\mathrm{D} / \mathrm{B}$.

A recent study, again based mainly on accessions conserved in France, describes the outcome of sequence-based genotyping of 405 plum accessions (Zhebentyayeva et al. 2019), 34 of which were represented also in our study. Greengages (mainly 'Reine-Claude Verte' and its offspring) and a group called "DAP" (mainly 'd'Ente' and its offspring) constituted the two best defined pomological groups. Also, mirabelles and 'European plums' formed clusters, with $\mathrm{P} / \mathrm{Z}$ prunes in a subcluster within the 'European plums'. It should, however, be noted that most of the pomological groups were very narrowly defined whereas the definition used for 'European plum' was relatively wide and included several accessions treated as D/B in our study.

\section{Pomological plum groups}

In our study, several different pomological groups were defined, and to a considerable extent verified by SSR data.

1. Egg plums sensu lato. Proper egg plums are mostly oval and large-fruited (above 40 grams) and belong to subsp. domestica (or subsp. intermedia in some treatises). We chose to also classify several small-fruited cultivars as egg plums when they could not be referred to any of the other pomological groups. In the FCA (Fig. 3), large-fruited egg plums occurred at one end of the 2-dimensional plot, with 
small-fruited egg plums and greengages as closest neighbours. In the Bayesian structure analysis, almost all large-fruited egg plums clustered together with greengages, and were very different from groups with affinity to subsp. insititia. By contrast, some of the small-fruited egg plums were intermingled with damsons and bullaces, and probably represent hybridisation products.

2. Greengages. A widely grown genotype named 'Reine-Claude Verte' but with many synonyms as well, has been identified using SSR loci (Gharbi et al. 2014) as well as DNA sequencing (Zhebentyayeva et al. 2019). This particular greengage is reported to have been introduced to Europe from Armenia through Greece and Italy, and cultivated in France since the end of the 15th century. Depending on author, a variable number of other genotypes, some of which appear to be direct offspring of 'Reine-Claude Verte', are included in the pomological group 'greengages'. This group was very homogenous in a study of mainly Spanish germplasm and some reference cultivars (Urrestarazu et al. 2018). In a sequence-based study, greengages also formed a well-defined group (Zhebentyayeva et al. 2019). By contrast, greengages were less well circumscribed in our study. Several of our greengages were, however, classified as 'European plum' by Zhebentyayeva et al. (2019), as well as in the study of Horvath et al. (2011) in which many also showed admixture. The affinity to large-fruited egg plums is, however, much larger than the affinity to subsp. insititia, and we suggest that greengages should be treated as var. italica under subsp. domestica.

3. Mirabelles. Although 5 of the 6 mirabelles grouped close together in our Bayesian structure analysis, they all demonstrated an admixed genome and could not be allocated to either subsp. domestica or subsp. insititia. In the FCA, they were closer to subsp. insititia and showed some affinity also to the two groups of prunes. An origin involving crosses with different ancestral groups was suggested by Horvath et al. (2011) who also found admixed genomes. By contrast, Halapija Kazija et al. (2014) analysed 25 mostly Croatian mirabelle accessions which were genetically homogenous and appeared to have a very similar ancestry. It is, however, not possible to ascertain how well these Croatian accessions represented the diversity of mirabelles since no other mirabelle samples were included in their study.

4. P/A prunes. Two separate types of prunes are sometimes mentioned in the horticultural literature and can be treated as separate entities (Horvath et al. 2011). The French type is represented primarily by the 'Prune d'Agen' also known as 'd'Ente', which dates back to the times of the crusades when Benedictine monks brought the 'Date Plum' from Turkey or Persia to Europe (Hedrick 1911). These cultivars, in Table 1 designated as ' $\mathrm{P} / \mathrm{A}$ ', are described as having medium-sized, long to egg-shaped fruits and flat stones with pointed ends. In a DNA sequence-based study, DAP (mainly 'd'Ente' and its offspring, roughly equivalent to P/A in the present study) formed a well-defined group but almost all of the studied accessions belonged to the same clone (Zhebentyayeva et al. 2019). Since they also had a unique cpDNA haplotype, DAP are probably derived from a unique hybridisation event that did not involve any plums from the other pomological groups. Our study included only 5 P/A accessions; the two French accessions and their offspring clustered together with other subsp. domestica accessions in the Structure analysis while the remaining two P/A accessions were admixed and probably had a different origin. A similar situation was reported by Horvath et al. (2011) and this was attributed to crosses with local germplasm.

5. P/Z prunes. The second type of plums for drying is the Central-Southeast European 'Quetsche' (in French) or 'Zwetsche' (in German), sometimes also known as German/Austrian prunes 'Hauszwetschen' or Hungarian prunes 'Musquée de Besztercei'. These cultivars, defined as 'P/Z' in Table 1, have smaller, oval fruits and thicker stones with rounded ends. The largest group of identical genotypes in our study contained P/Z accessions 'Besztercei', 'Bistrica', 'Požegača' and the somewhat less similar (i.e. fewer shared alleles) 'Tölcsér Koronájú'. In a previous study, 30 out of 33 accessions from Bosnia and Herzegovina, Croatia and Serbia labelled as 'Požegača' or 'Bistrica', were either identical or similar in all but one or two SSR loci (Halapija Kazija et al. 2011); in addition, 'Hauszwetche' from Austria shared the most common genotype. In yet another study, 6 clones of 'Besztercei' proved to 
have unique but still very similar SSR marker profiles, with 'Besztercei Szilva' regarded as a synonym for 'Požegača' (Makovics-Zsohár et al. 2017). According to our study, other cultivars in this group are e.g. the German 'Bühler Frühzwetsche' and 'Ersinger Frühzwetsche' as well as the Belgian 'Altesse dorée' and 'Sainte-Catherine'. The Italian 'Duránci' (classified as a small fruited egg plum in our study) clustered closely with 'Bühler Frühzwetche' and 'Besztercei' in a study by Makovics-Zsohár et al. (2017) and probably also belongs to the P/Z group. By contrast, the P/A cultivar 'Stanley' and its offspring 'Čačanska Lepotica' were very different from the 'Besztercei'/'Duránci'/'Bühler Früzwetsche' group (Makovics-Zsohár et al. 2017), again suggesting that P/Z and P/A prunes differ genetically.

$\mathrm{P} / \mathrm{Z}$ (and sometimes also P/A) cultivars are sometimes referred to as 'prunes de Damas' or 'damascene plums' and have occasionally been classified as damsons (Horvath et al. 2011) although this is usually reserved for a group of landrace cultivars in subsp. insititia with small and sour fruits. Both P/A and P/Z accessions have instead been classified as subsp. domestica in several other studies (Milošević and Milošević 2012; Makovics-Zsohár et al. 2017). In our study, the P/Z accessions were quite similar to damsons and bullaces, and appear to be best treated as subsp. insititia.

6. Damsons/bullaces. The English damsons and bullaces are well-known but rather primitive plum types that have been selected especially for culinary purposes, and are usually treated as subsp. insititia although e.g. the German 'Spilling' has been classified as $P$. domestica subsp. pomariorum. Corresponding plum types have been selected and grown also in many other countries, and are assigned to ' $\mathrm{D} / \mathrm{B}$ ' in Table 1 . The $\mathrm{D} / \mathrm{B}$ accessions are strongly differentiated from commercially cultivated plums (egg plums and greengages). Thus, most of the analysed Norwegian local plum germplasm as well as some Swedish landrace accessions of D/B (e.g. 'Krikon') were quite distinctive from international reference cultivars (Sehic et al. 2015).

\section{Conclusions}

Geographic origin and pomological assignment were equally important factors in explaining a descriptorbased grouping structure in European plum germplasm. By contrast, pomological assignment was more important than geographic origin according to SSR marker data. Egg plums sensu lato and greengages can be classified as subsp. domestica while the genetically more diverse damsons and bullaces along with the prunes of the Central-Southeast European type (Zwetschen) show more affinity to subsp. insititia. The small and possibly heterogeneous (in our study) groups with mirabelles and prunes of the French d'Agen type, take an intermediate position suggesting a hybridogenic origin.

In this study, several different approaches were used in order to infer the underlying genetic structure of the examined plum germplasm. The importance of geographic origin in explaining a descriptor-based grouping structure in European plum germplasm, could at least in part be attributed to differences in climate and orchard management as well as differences in character scorings among the collection sites throughout Europe. In this aspect, characterization based on SSR markers has a clear advantage. Furthermore, the obtained SSR marker data was evaluated using several different approaches (FCA, Bayesian Structure analysis and DAPC) in order to verify the classification of the examined accessions into different pomological groups. Since it is highly probable that a number of the examined accessions originate from hybridisation between members of different pomological groups, the ability of the Bayesian Structure analysis to identify admixed genotypes is very useful, giving a certain advantage to this approach over DAPC. The factorial correspondence analysis (FCA) efficiently illustrates the relationships among individual genotypes as well as between pomological groups, and thus complements the Structure analysis.

\section{Acknowledgements}


Financial support was obtained through the ECPGR Activity Grant Scheme (Phase IX) First Call (PRUNDOC Project) and Fifth Call (Prunus Alignment Project). Valuable information on the plant material was supplied by Zsusanna Békefi, Hedi Kaldmäe, Erika Zetochová.

\section{Conflict of interest}

The authors declare that they have no conflict of interest.

\section{References}

Aranzana MJ, Hernández Mora JR, Micheletti D, Micali S, Nazzicari N, Pacheco I, Foschi S, Barreneche T, Quilot-Turion B, Wang L, Ma R, Li X, Iglesias I, Carbó J, Troggio M, Banchi E, Aramini V, Dettori MT, Caprera A, da Silva Linge C, Pascal T, Lambert P, Gao Z, Verde I, Bassi D, Rossini L, Laurens F, Arús P (2017) Exploring and exploiting phenotypic and genetic diversity in peach: identification of major genes and QTLs by GWAS. Acta Hortic 1172:419-424.

Bourguiba H, Audergon JM, Krichen L, Trifi-Farah N, Mamouni A, Trabelsi S, D’Onofrio C, Asma BM, Santoni S, Khadari B (2012) Loss of genetic diversity as a signature of apricot domestication and diffusion into the Mediterranean Basin. BMC Plant Biol 12:49. https://doi.org/10.1186/1471-2229$\underline{12-49}$

Decroocq V, Hagen LS, Favé M-G, Eyquard J-P, Pierronnet A (2004) Microsatellite markers in the hexaploid Prunus domestica species and parentage lineage of three European plum cultivars using nuclear and chloroplast simple-sequence repeats. Mol Breed 13:135-142.

Dray S, Dufour AB (2007) The ade4 package: implementing the duality diagram for ecologists. J Statistical Software 22(4): 1-20.

Earl DA, Von Holdt BM (2011) Structure harvester: a Website and program for visualizing STRUCTURE output and implementing the Evanno method. Conserv Genet Resour 4:359-361.

Evanno G, Regnaut S, Goudet J (2005) Detecting the number of clusters of individuals using the software STRUCTURE: a simulation study. Mol Ecol 14:2611-2620.

Excoffier L, Smouse PE, Quattro JM (1992) Analysis of molecular variance inferred from metric distances among DNA haplotypes: application to human mitochondrial DNA restriction data. Genetics 131:479-491.

Gharbi O, Wünsch A, Rodrigo J (2014) Characterization of accessions of 'Reine Claude Verte' plum using Prunus SRR and phenotypic traits. Sci Hortic 169:57-65.

Gower JC (1971) A general coefficient of similarity and some of its properties. Biometrics 23:623-637.

Grahić A, Grahić J (2017) MADC - Marker Analysis Data Compiler user's Manual. (www.divisionagro.ba/apps/docs/madc-marker-analysis-data-compiler/user-manual)

Halapija Kazija D, Vujević P, Jelačić T, Milinović B, Pejić I, Simon S, Zulj M, Drkenda P, Gaši F, Kurtović M, Nikolić D (2013) Genetic identification of 'Bistrica' and its synonyms 'Pozegača' and 'Hauszwetsche' (Prunus domestica L.) using SSRs. Acta Hortic 976:285-289.

Halapija Kazija D, Jelačić T, Vujević P, Milinović B, Čiček D, Biško A, Pejić I, Šimon S, Žulj Mihaljević M, Pecina M, Nikolić D, Grahić J, Drkenda P, Gaši F (2014) Plum germplasm in Croatia and neighbouring countries assessed by microsatellites and DUS descriptors. Tree Genet Genom 10:761-778.

Hardy OJ, Vekemans X (2002) SPAGeDi: a versatile computer program to analyse spatial genetic structure at the individual or population levels. Mol Ecol Notes 2:618-620.

Hedrick UP (1911) The plums of New York. New York State Deparment of Agriculture 28, Annual Report, vol. 3. part III. Lyon Company, Albany.

Hjeltnes SH, Giovannini D, Blouin M, Benedikova D, Drogoudi P, Höfer M, Lacis G, Ognjanov V, Lateur M, Engels JM, Maggioni L (2017) PRUNDOC - a project to define accessions for the European Collection. Acta Hortic 1175:19-24. https://doi.org/10.17660/ActaHortic.2017.1175.5 
Horvath A, Balsemin E, Barbot JC, Christmann H, Manzano G, Reynet P, Laigret F, Mariette S (2011) Phenotypic variability and genetic structure in plum (Prunus domestica L.), cherry plum ( $P$. cerasifera Ehrh.) and sloe (P. spinosa L.). Sci Hortic 129:283-293.

Jombart T, Devillard S, Balloux F (2010) Discriminant analysis of principal components: a new method for the analysis of genetically structured populations. BMC Genet 11:94. https ://doi.org/10.1186/1471-2156-11-94

Kassambara A, Mundt F (2017) Factoextra: Extract and Visualize the Results of Multivariate Data Analyses. R package version 1.0.5. https://CRAN.R-project.org/package=factoextra.

Laurens F, Aranzana MJ, Arús P, Bassi D, Bink M, Bonany J, Caprera A, Corelli-Grapadelli L, Costes E, Durel CE, Mauroux JB, Muranty H, Nazzicari N, Patocchi A, Peil A, Quilot-Turion B, Rossini L, Stella A, Troggio M, Velasco R, van de Weg E (2018) An integrated approach for increasing breeding efficiency in apple and peach in Europe. Hortic Res 2018 Mar 1;5:11. doi: 10.1038/s41438018-0016-3.

Le S, Josse J, Husson F (2008) FactoMineR: An R Package for Multivariate Analysis. J Statistical Software 25(1):1-18. 10.18637/jss.v025.i01

Ligges U, Mächler M (2003) Scatterplot3d - an R Package for Visualizing Multivariate Data. J Statistical Software 8(11):1-20.

Maechler M, Rousseeuw P, Struyf A, Hubert M, Hornik K (2018) Cluster: Cluster Analysis Basics and Extensions. R package version 2.0.7-1.

Makovics-Zsohár N, Tóth M, Surányi D, Kovács S, Hegedüs A, Halász J (2017) Simple sequence repeat markers reveal Hungarian plum (Prunus domestica L.) germplasm as a valuable gene resource. HortScience 52:1655-1660.

Mantel N (1967) The detection of disease clustering and a generalized regression approach. Cancer Res 27:209-220.

Mariette S, Tavaud M, Arunyawat U, Capdeville G, Millan M, Salin F (2010) Population structure and genetic bottleneck in sweet cherry estimated with SSRs and the gametophytic self-incompatibility locus. BMC Genet 2010;11:77. https://doi.org/10.1186/1471-2156-11-77

Meirmans P, Van Tienderen P (2004) Genotype and genodive: two programs for the analysis of genetic diversity of asexual organisms. Mol Ecol Notes 4:792-794.

Merkouropoulos G, Ganopoulos I, Tsaftaris A, Papadopoulos I, Drogoudi P (2016) Combination of High Resolution Melting (HRM) analysis and SSR molecular markers speeds up plum genotyping: case study genotyping the Greek plum GeneBank collection. Plant Genet Resour 15:366-375, doi: $10.1017 / \mathrm{S} 1479262116000022$

Micheletti D, Dettori MT, Micali S, Aramini V, Pacheco I, Da Silva Linge C, Foschi S, Banchi E, Barreneche T, Quilot-Turion B, Lambert P, Pascal T, Iglesias I, Carbó J, Wang L-r, Ma R-j, Li Xw, Gao Z-s, Nazzicari N, Troggio M, Bassi D, Rossini L, Verde I, Laurens F, Arús P, Aranzana MJ (2015) Whole-genome analysis of diversity and SNP-major gene association in peach germplasm. PLOS ONE 10(9), doi: 10.1371/journal.pone.0136803

Milošević T, Milošević N (2012) Phenotypic diversity of autochtonous European (Prunus domestica L.) and damson (Prunus insititia L.) plum accessions based on multvariate analysis. Hortic Sci (Prague) 39(1):8-20.

Muller LAH, McCusker JH (2009) Microsatellite analysis of genetic diversity among clinical and nonclinical Saccharomyces cerevisiae isolates suggests heterozygote advantage in clinical environments. Mol Ecol 18:2779-2786.

Muranty H, Denancé C, Feugey L, Crépin J-L, Barbier Y, Tartarini S, Ordidge M, Troggio M, Lateur M, Nybom H, Paprstein F, Laurens F, Durel CE. Using whole-genome SNP data to reconstruct multigeneration pedigrees involving numerous old apple cultivars. Submitted. 
Nybom H, Garkava-Gustavsson L (2009) Gene banks: for breeding, research or public entertainment. Acta Hortic 814:71-75.

Nei M (1978) Estimation of average heterozygosity and genetic distance from a small number of individuals. Genetics 89:583-590.

Ohta T, Kimura M (1973) A model of mutation appropriate to estimate the number of electrophoretically detectable alleles in a finite population. Genet Res 22:201-204.

Ordidge M, Kirdwichai P, Baksh MF, Venison EP, Gibbings JG, Dunwell JM (2018) Genetic analysis of a major international collection of cultivated apple varieties reveals previously unknown historic heteroploid and inbred relationships. PLOS One, Sept 12, doi.org/10.1371/journal.pone.0202405

Oksanen J, Guillaume Blanchet F, Friendly M, Kindt R, Legendre P, McGlinn D, Minchin PR, O'Hara RB, Simpson GL, Solymos P, Henry M, Stevens H, Szoecs E, Wagner H (2018). Vegan: Community Ecology Package. R package version 2.5-2. https://CRAN.R-project.org/package=vegan.

Pagès J (2014) Multiple Factor Analysis by Example Using R. Chapman \& Hall/CRC The R Series London 272 p.

R Core Team (2018) R: A language and environment for statistical computing. R Foundation for Statistical Computing, Vienna, Austria. Available from http://www.R-project.org/

Reales A, Sargent DJ, Tobutt KR, Rivera D (2010) Phylogenetics of Eurasian plums. Prunus L. section Prunus (Rosaceae), according to coding and non-coding chloroplast DNA sequences. Tree Genet Genom 6:37-45.

Rohlf FJ (2000) "NTSYS-Pc: Numerical Taxonomy and Multivariate Analysis System (Version 2.1)," Exeter Software, Setauket, NY.

Pritchard JK, Stephens M, Donnelly P (2000) Inference of population structure using multilocus genotype data. Genetics 155:945-959.

Sehic J, Nybom H, Hjeltnes SH, Gaši F (2015) Genetic diversity and structure of Nordic plum germplasm preserved ex situ and on-farm. Sci Horticult 160:195-202.

Tamura K, Stecher G, Peterson D, Filipski A, Kumar S (2013) MEGA6: Molecular Evolutionary Genetics Analysis Version 6.0. Mol Biol Evol 30: 2725-2729.

Urrestarazu J, Denancé C, Ravon E, Guyader A, Guisnel R, Feugey L, Poncet C, Lateur M, Houben P, Ordidge M, Fernandez-Fernandez F, Evans KM, Paprstein F, Sedlak J, Nybom H, GarkavaGustavsson L, Miranda C, Gassmann J, Kellerhalls M, Suprun I, Pikunova AV, Krasova NG, Torutaeva E, Dondini L, Tartarini S, Laurens F, Durel CE (2016) Analysis of the genetic diversity and structure across a wide range of germplasm reveals prominent gene flow in apple at the European level. BMC Plant Biol. 16(1):130. doi: 10.1186/s12870-016-0818-0.

Urrestarazu J, Muranty H, Denancé C, Leforestier D, Ravon E, Guyader A, Guisnel R, Feugey L, Aubourg S, Celton J-M, Daccord N, Dondini L, Gregori R, Lateur M, Houben P, Ordidge M, Paprstein F, Sedlak J, Nybom H, Garkava-Gustavsson L, Troggio M, Bianco L, Velasco R, Poncet C, Théron A, Moriya S, Bink MCAM, Laurens F, Tartarini S, Durel CE (2017) Genome-wide association mapping of flowering and ripening periods in apple. Frontiers Plant Sci, 10 Nov 2017, https://doi.org/10.3389/fpls.2017.01923

Urrestarazu J, Errea P, Miranda C, Santesteban LG, Pina A (2018) Genetic diversity of Spanish Prunus domestica L. germplasm reveals a complex genetic structure underlying. PLOS ONE 13(4): e0195591.

Vigouroux Y, Glaubitz JC, Matsuoka Y, Goodman MM, Sánchez GJ, Doebley J (2008) Population structure and genetic diversity of New World maize races assessed by DNA microsatellites. Amer J Bot 95:1240-1253.

Woldring H (2000) On the origin of plums: a study of sloe, damson, cherry plum, domestic plums and their intermediates. Palaeohistoria 40:535-562. 
Xuan H, Ding Y, Spann D, Möller O, Büchele M, Neumüller M (2011) Microsatellite markers (SSR) as a tool to assist in identification of European plum (Prunus domestica L.). Acta Hort 918:689-692.

Zhebentyayeva T, Shankar V, Scorza R, Callahan A, Ravelonandro C, Castro S, DeJong T, Saski CA, Dardick C (2019) Genetic characterization of worldwide Prunus domestica (plum) germplasm using sequence-based genotyping. Hortic Res 6:12, doi 10.1038/s41438-018-0090-6

Table 1. All accessions studied, with accession code including country for sampling (BEL Belgium, DEU Germany, DNK Denmark, EST Estonia, FRA France, GBR Great Britain, GRC Greece, HUN Hungary, ITA Italy, LVA Latvia, NOR Norway, SRB Serbia, SVO Slovakia, SWE Sweden, REF Reference), cultivar name and country of origin if different from sampling (CAN Canada, CZE Czech Republic, USA Unites States of America), fruit weight, fruit shape, fruit basic colour, fruit over colour (amount of covering and colour), pomological group ( $\mathrm{E}=$ egg plum sensu lato, $\mathrm{G}=$ greengage, $\mathrm{P} / \mathrm{A}=\mathrm{prune}$ of French d'Agen type, $\mathrm{P} / \mathrm{Z}=$ Central-Southeast European prune/Zwetsche, $\mathrm{M}=$ mirabelle, $\mathrm{D} / \mathrm{B}=$ damson/bullace, $\mathrm{C}=P$. cerasifera,$?=$ possibly diploid). Each accession colour coded; green $=$ greengage, dark orange $=\mathrm{egg}$ plum with fruit weight $>40 \mathrm{~g}$, pale orange=egg plum $<40 \mathrm{~g}$, violet=P/A prune, grey=P/Z prune, yellow $=$ mirabelle, dark blue $=$ damson/bullace $>25 \mathrm{~g}$, pale blue=damson/bullace $<25 \mathrm{~g}$, purple=diploid. Entries ordered according to a Bayesian genetic structure analysis (Fig. 6), and assignment to a reconstructed panmictic population (RPP) for $K=2, K=4$ and $K=8$, with probability of membership $q I$ $>80 \%$ (values within parentheses $80 \%>q I>50 \%$ ), as well as assignment to discriminant analysis of principal components (DAPC) clusters, selected according to the Bayesian information criterion (BIC).

Table 2. Phenotypic traits scored in situ for 104 local plum accessions according to the List of Plum Descriptors prioritized during PRUNDOC. Additional categories (italicized) were added to most of the observed traits in order to accurately classify a wide range of distinct, as well as transitional phenotypic forms found among the examined accessions.

Table 3. Number of alleles for eight SSR loci, allele size range and Nei's gene diversity, calculated for all plum genotypes, reference cultivars, local accessions, as well as for $\mathrm{K}=2$ reconstructed panmictic populations (RPPs) and admixed accessions. For origin and DNA sequences of these loci, see Sehic et al. (2015).

Fig. 1. Factorial analysis of mixed data (FAMD)-based dendrogram using descriptor data for 104 local plum accessions.

Fig. 2. Unweighted pair group method with arithmetic mean (UPGMA)-based dendrogram using molecular data for 104 local plum accessions and 8 reference cultivars.

Fig. 3. Two-dimensional plot of a factorial correspondence analysis (FCA) of the molecular data for 106 plum accessions divided into 7 pomological groups: egg plums large (Ebig, fruit over $40 \mathrm{~g}$ ), egg plums small (Esmall, fruit below $40 \mathrm{~g}$ ), greengages $(\mathrm{G})$, mirabelles (M), French type prunes (P/A), Central-Southeast European type prunes (P/Z) and damsons and bullaces (D/B).

Fig. 4. Two-dimensional plot of a factorial correspondence analysis (FCA) of the molecular data for 106 plum accessions divided into 5 groups based on geographic origin in Europe: central, eastern, northern, north-eastern and western.

Fig. 5. Plot of delta K values from the Structure analyses (a) and Bayesian information criterion (BIC) 
values (b), based on SSR data on 104 local plum accessions and 8 reference cultivars.

Fig. 6. Bar plot of the results from three Bayesian genetic structure analyses of 112 plum accessions with $K=2,6$ and 8, respectively ( $\mathrm{a}, \mathrm{b}$ and $\mathrm{c}$ ), as well as from discriminant analysis of principal components (DAPC) based on two clusters (d). For accession names, see Table 1. 
Table 1. All accessions studied, with accession code including country for sampling (BEL Belgium, DEU Germany, DNK Denmark, EST Estonia, FRA France, GBR Great Britain, GRC Greece, HUN Hungary, ITA Italy, LVA Latvia, NOR Norway, SRB Serbia, SVO Slovakia, SWE Sweden, REF Reference), cultivar name and country of origin if different from sampling (CAN Canada, CZE Czech Republic, USA Unites States of America), fruit weight, fruit shape, fruit basic colour, fruit over colour (amount of covering and colour), pomological group (E=egg plum sensu lato, $\mathrm{G}=$ greengage, $\mathrm{P} / \mathrm{A}=$ prune of French d'Agen type, $\mathrm{P} / \mathrm{Z}=$ Central-Southeast European prune/Zwetsche, $\mathrm{M}=\mathrm{mirabelle}, \mathrm{D} / \mathrm{B}=\mathrm{damson} / \mathrm{bullace}$, $\mathrm{C}=P$. cerasifera, ?=possibly diploid). Each accession colour coded; green=greengage, dark orange $=$ egg plum with fruit weight $>40 \mathrm{~g}$, pale orange=egg plum $<40 \mathrm{~g}$, violet=P/A prune, grey=P/Z prune, yellow=mirabelle, dark blue=damson/bullace $>25 \mathrm{~g}$, pale blue $=$ damson/bullace $<25$ $\mathrm{g}$, purple=diploid. Entries ordered according to a Bayesian genetic structure analysis (Fig. 6), and assignment to a reconstructed panmictic population (RPP) for $K=2, K=4$ and $K=8$, with probability of membership $q I>80 \%$ (values within parentheses $80 \%>q I>50 \%$ ), as well as assignment to discriminant analysis of principal components (DAPC) clusters, selected according to the Bayesian information criterion (BIC).

\begin{tabular}{|c|c|c|c|c|c|c|c|c|c|c|c|c|}
\hline $\begin{array}{l}\text { Sampl } \\
\text { e }\end{array}$ & Accession & Cultivar & $\begin{array}{l}\text { Weight } \\
\text { (g) }\end{array}$ & Shape & $\begin{array}{l}\text { Basic } \\
\text { colour }\end{array}$ & Over colour & $\begin{array}{c}\text { Classificatio } \\
\mathbf{n}\end{array}$ & $\begin{array}{c}\text { No. in Fig } \\
5 \\
\end{array}$ & $\begin{array}{c}\mathrm{RPP}, \\
\mathrm{k}=2\end{array}$ & $\begin{array}{c}\mathrm{RPP}, \\
\mathrm{k}=6\end{array}$ & $\begin{array}{c}\text { RPP, } \\
\mathrm{k}=8\end{array}$ & $\begin{array}{c}\text { DAP } \\
\mathbf{C}\end{array}$ \\
\hline BEL4 & $\begin{array}{l}\text { CRA PRU } \\
370\end{array}$ & Reine-Claude Souffriau & $41-55$ & round & $\begin{array}{l}\text { violet/blue } \\
\text { yellow/gree }\end{array}$ & none & G & 1 & 1 & 1 & 1 & 1 \\
\hline GRC6 & PD0004 & Mpardaki Circular (BEL) & $26-40$ & round & $\mathrm{n}$ & none & G & 2 & 1 & 1 & 1 & 1 \\
\hline EST4 & EST2186 & Tartu Punane & $41-55$ & ovate & $\begin{array}{l}\text { green } \\
\text { yellow/gree }\end{array}$ & violet & $\mathrm{E}$ & 3 & 1 & 1 & 1 & 1 \\
\hline NOR3 & 1429 & Helgøyplomme (FRA) & $41-55$ & oval & $\begin{array}{l}\mathrm{n} \\
\text { yellow/gree }\end{array}$ & medium, pink & G & 4 & 1 & 1 & 1 & 1 \\
\hline GBR7 & 1976-046 & Victoria & $41-55$ & ovate & $\mathrm{n}$ & medium, red & $\mathrm{E}$ & 5 & 1 & (1) & (1) & 1 \\
\hline FRA15 & P3692 & Bonjour & $41-55$ & oblong & violet/blue & slight, red & $\mathrm{E}$ & 6 & 1 & 1 & 1 & 1 \\
\hline DEU6 & PFL0012 & Gräfin Cosel & $41-55$ & elliptic & purple/red & wide, black & $\mathrm{E}$ & 7 & 1 & (2) & & 1 \\
\hline EST2 & EST2170 & Ave & $41-55$ & ovate & purple/red & violet & $\mathrm{P} / \mathrm{Z} \times \mathrm{E}$ & 8 & 1 & 1 & 1 & 1 \\
\hline REF2 & & Valor (CAN) & $41-55$ & ovate & purple/red & wide, black & $\mathrm{E}$ & 9 & 1 & & & 1 \\
\hline LVA9 & LVADPru2 & Julius (EST) & $26-40$ & elliptic & violet/blue & wide, violet & $\mathrm{E}$ & 10 & 1 & (1) & & 1 \\
\hline GBR3 & 2003-002 & Grand Duke & $56-70$ & ovate & purple/red & none & $\mathrm{E}$ & 11 & 1 & 1 & 1 & 1 \\
\hline REF8 & & Topfirst (DEU) & $26-40$ & ovate & $\begin{array}{l}\text { violet/blue } \\
\text { yellow/gree }\end{array}$ & violet & $\mathrm{E}$ & 12 & 1 & (2) & & 1 \\
\hline EST1 & EST2169 & Amitar & $41-55$ & oblong & $\begin{array}{l}\mathrm{n} \\
\text { yellow/gree }\end{array}$ & $\begin{array}{l}\text { violet } \\
\text { medium, }\end{array}$ & $\mathrm{E}$ & 13 & 1 & 1 & 1 & 1 \\
\hline GBR5 & $2000-127$ & Late Orange & $>70$ & elliptic & $\mathrm{n}$ & orange & $\mathrm{E}$ & 14 & 1 & 1 & (1) & 1 \\
\hline LVA8 & LVADPru1 & Suhkruploom (EST) & $11-25$ & elliptic & $\begin{array}{l}\text { dark blue } \\
\text { yellow/gree }\end{array}$ & slight, violet & $\mathrm{P} / \mathrm{Z} \times \mathrm{E}$ & 15 & 1 & (1) & & 1 \\
\hline GBR6 & $1949-255$ & Utility & $56-70$ & elliptic & $\begin{array}{l}\mathrm{n} \\
\text { yellow/gree }\end{array}$ & wide, red & E & 16 & 1 & & & 1 \\
\hline SWE2 & BF0229 & Hackman & $56-70$ & ovate & $\mathrm{n}$ & slight, orange & G & 17 & 1 & 1 & 1 & 1 \\
\hline
\end{tabular}




\begin{tabular}{|c|c|c|c|c|c|c|c|c|c|c|c|}
\hline BEL1 & $\begin{array}{l}\text { CRA PRU } \\
137\end{array}$ & Belle de Louvain & $56-70$ & elliptic & purple/red & wide, violet & $\mathrm{E}$ & 18 & 1 & 1 & 1 \\
\hline FRA2 & P3727 & D'Ente Double & $41-55$ & elliptic & purple/red & violet & $\mathrm{P} / \mathrm{A}$ & 19 & 1 & 2 & 7 \\
\hline SWE6 & BF0337 & Opal & $26-40$ & heart-shaped & orange & medium, violet & Gx E & 20 & 1 & 1 & 1 \\
\hline REF4 & & Reine-Claude Violette (FRA) & $26--40$ & round-ovate & $\begin{array}{l}\text { violet/blue } \\
\text { yellow/gree }\end{array}$ & wide, violet & G & 21 & 1 & 2 & 7 \\
\hline FRA8 & P0389 & Reine-Claude Davion & $26-40$ & elliptic & $\begin{array}{l}\mathrm{n} \\
\text { yellow/gree }\end{array}$ & slight, red & G & 22 & 1 & (1) & \\
\hline FRA5 & P0062 & Abricotée Jaune & $26-40$ & elliptic & $\mathrm{n}$ & slight, orange & G & 23 & 1 & 1 & 1 \\
\hline EST5 & EST2250 & Kihelkonna & $41-55$ & ovate & $\begin{array}{l}\text { purple/red } \\
\text { yellow/gree }\end{array}$ & red & $\mathrm{E}$ & 24 & 1 & (2) & \\
\hline HUN6 & prudo530 & Tarka perdrigon (FRA?) & $26-40$ & round & n & wide, red/violet & G & 25 & 1 & 2 & \\
\hline GBR1 & $1977-186$ & Czar & $26-40$ & elliptic & purple/red & wide, black & E & 26 & 1 & & \\
\hline SWE3 & BF0237 & Herman & $26-40$ & ovate & purple/red & wide, violet & E & 27 & 1 & 2 & \\
\hline DNK4 & POM B70 & Kongeblomme & $41-55$ & round & orange & medium, violet & G & 28 & 1 & 2 & \\
\hline FRA10 & P0449 & Impériale Epineuse & $41-55$ & oblong & purple/red & medium, violet & $\mathrm{E}$ & 29 & 1 & 2 & 7 \\
\hline SWE5 & BF0249 & Jubileum & $>70$ & elliptic & purple/red & wide, violet & $\mathrm{E}$ & 30 & 1 & (2) & \\
\hline DEU4 & PFL0030 & Ruth Gerstetter & $26-40$ & elliptic & violet/blue & wide, black & $\mathrm{E}$ & 31 & 1 & 2 & \\
\hline ITA9 & 214 & Prunella & $26-40$ & round & $\begin{array}{l}\text { green } \\
\text { yellow/gree }\end{array}$ & wide, violet & E & 32 & 1 & 2 & 7 \\
\hline DEU3 & $\begin{array}{l}\text { PFL0011 } \\
\text { CRA PRU }\end{array}$ & Reine-Claude d'Althann (CZE) & $41-55$ & round & $\begin{array}{l}\mathrm{n} \\
\text { yellow/gree }\end{array}$ & medium, violet & G & 33 & 1 & 2 & (7) \\
\hline BEL3 & 114 & Belle de Thuin & $56-70$ & elliptic & $\mathrm{n}$ & none & E & 34 & 1 & & \\
\hline SRB3 & PD 0103 & Čačanska Lepotica & $26-40$ & elliptic & dark blue & violet & $\mathrm{P} / \mathrm{A} \times \mathrm{E}$ & 35 & 1 & (2) & \\
\hline EST3 & EST2176 & Liisu & $41-55$ & ovate & purple/red & violet & E & 36 & 1 & (3) & \\
\hline ITA1 & 264 & Susino Secondo & $56-70$ & oblong & purple/red & wide, violet & E & 37 & 1 & & \\
\hline FRA11 & P0812 & Double Robe & $26-40$ & ovate & $\begin{array}{l}\text { violet/blue } \\
\text { yellow/gree }\end{array}$ & medium, red & $\mathrm{P} / \mathrm{A}$ & 38 & 1 & 2 & 7 \\
\hline LVA6 & LVA01009 & Lāse & $41-55$ & oblong & $\mathrm{n}$ & none & E & 39 & 1 & (3) & \\
\hline FRA7 & P0328 & Madame Guttin & $26-40$ & ovate & violet/blue & medium, red & $\mathrm{E}$ & 40 & 1 & (1) & \\
\hline REF7 & & Stanley (USA) & c. $55-60$ & oblong & $\begin{array}{l}\text { violet/blue } \\
\text { yellow/gree }\end{array}$ & & $\mathrm{P} / \mathrm{A}$ & 41 & 1 & & \\
\hline LVA1 & LVA01016 & Zemgale & $26-40$ & round & $\mathrm{n}$ & wide, red & $\mathrm{E}$ & 42 & 1 & 2 & (7) \\
\hline NOR1 & 255 & Edda & $41-55$ & heart-shaped & $\begin{array}{l}\text { dark blue } \\
\text { yellow/gree }\end{array}$ & wide, violet & E & 43 & 1 & & \\
\hline BEL6 & CRA PRU 57 & Wignon & $26-40$ & ovate & $\mathrm{n}$ & wide, violet & $\mathrm{E}$ & 44 & 1 & & \\
\hline FRA3 & P0302 & Impériale Murat & $>70$ & oblong & purple/red & medium, violet & $\mathrm{E}$ & 45 & 1 & & \\
\hline
\end{tabular}




\begin{tabular}{|c|c|c|c|c|c|c|c|c|c|c|c|}
\hline GBR2 & $1977-187$ & Marjorie's Seedling & $41-55$ & elliptic & green & medium, violet & $\mathrm{E}$ & 46 & 1 & (1) & \\
\hline ITA6 & 147 & Lazzarinu & $11-25$ & elliptic & $\begin{array}{l}\text { purple/red } \\
\text { yellow/gree }\end{array}$ & wide, blackish & I & 47 & 1 & (2) & \\
\hline NOR5 & 1398 & Tråneplomme & $26-40$ & drop-shaped & n & slight, orange & $\mathrm{E}$ & 48 & 1 & & \\
\hline SWE4 & BF0243 & Ive & $41-55$ & round & n & wide, violet & Gx E & 49 & 1 & 2 & \\
\hline REF5 & & Mirabelle de Nancy (FRA) & c. $7-8$ & round & yellow & slight, red & M & 50 & (1) & & \\
\hline LVA3 & LVA01013 & Latvijas Sarkanā Olplūme & $26-40$ & elliptic & $\begin{array}{l}\text { purple/red } \\
\text { yellow/gree }\end{array}$ & wide, violet & $\mathrm{E}$ & 51 & (1) & (3) & \\
\hline GRC2 & PD0005 & Glyka Skopelou & $26-40$ & elliptic & $\mathrm{n}$ & wide, violet & $\mathrm{P} / \mathrm{A}$ & 52 & (1) & & \\
\hline LVA7 & LVA02549 & Zilā Lāse & $11-25$ & oblong & violet/blue & wide, violet & $\mathrm{E}$ & 53 & (1) & & \\
\hline ITA4 & 438 & Agostana & $26-40$ & elliptic & $\begin{array}{l}\text { purple/red } \\
\text { yellow/gree }\end{array}$ & wide, violet & $\mathrm{P} / \mathrm{A}$ & 54 & (1) & & \\
\hline DNK2 & POM B141 & Gul Rosinblomme & $<10$ & round & $\mathrm{n}$ & none & M & 55 & (1) & & \\
\hline LVA2 & LVA01006 & Aizputes & $11-25$ & ovate & violet/blue & wide, black & $\mathrm{E}$ & 56 & (1) & & \\
\hline LVA4 & LVA01010 & Latvijas Dzeltenā Olplūme & $26-40$ & drop-shaped & yellow & none & $\mathrm{E}$ & 57 & (1) & 3 & \\
\hline SWE1 & Elite Pl. Stat. & Experimentalfältets Sviskon & $11-25$ & oblong & purple/red & wide, black & $\mathrm{P} / \mathrm{Z}$ & 58 & (1) & & \\
\hline FRA1 & P3691 & Reine-Claude Diaphane & $41-55$ & rounded flat & orange & red & G & 59 & (2) & & \\
\hline SVK2 & svk-pd-002 & Trenčianska Okrúhlička & $11-25$ & round & $\begin{array}{l}\text { violet/blue } \\
\text { yellow/gree }\end{array}$ & none & $\mathrm{D} / \mathrm{B}$ & 60 & (2) & & \\
\hline GRC3 & PD0006 & $\begin{array}{l}\text { Ksina Skopelou } \\
\text { Mirabelle Parfumée de }\end{array}$ & $26-40$ & elliptic & $\mathrm{n}$ & slight, red & $\mathrm{D} / \mathrm{B}$ & 61 & (2) & & \\
\hline FRA6 & P0072 & Septembre & $11-25$ & $\begin{array}{l}\text { round } \\
\text { ovate- }\end{array}$ & orange & medium, red & M & 62 & (2) & & \\
\hline REF6 & & Čačanska Rodna (SRB) & $26-40$ & oblong & $\begin{array}{l}\text { violet/blue } \\
\text { yellow/gree }\end{array}$ & violet & $\mathrm{P} / \mathrm{A} \times \mathrm{P} / \mathrm{Z}$ & 63 & (2) & (4) & (3) \\
\hline DNK3 & POM B25 & Gul Sveskeblomme & $11-25$ & elliptic & $\mathrm{n}$ & slight, pink & $\mathrm{P} / \mathrm{Z}$ & 64 & (2) & & \\
\hline BEL5 & CRA PRU 38 & Prune de Prince & $11-25$ & round & dark blue & slight, black & M & 65 & (2) & & \\
\hline ITA5 & 128 & Gaiotti & $26-40$ & round & purple/red & wide, black & $\mathrm{E}$ & 66 & (2) & (2) & \\
\hline DEU5 & PFL0022 & Mirabelle de Flotow (FRA) & $11-25$ & round & orange & slight, pink & M & 67 & (2) & & \\
\hline REF3 & & Hanita (DEU) & $26-40$ & oblong & violet/blue & & E & 68 & (2) & & \\
\hline FRA4 & P3720 & Oustenque Bleue & $11-25$ & elliptic & violet/blue & slight, pink & $\mathrm{D} / \mathrm{B}$ & 69 & (2) & & \\
\hline FRA18 & P3764 & Briquetch & $<10$ & elliptic & $\begin{array}{l}\text { green } \\
\text { yellow/gree }\end{array}$ & slight, orange & $\mathrm{D} / \mathrm{B}$ & 70 & 2 & & \\
\hline GRC1 & PD0003 & Mpardaki Elliptic & $26-40$ & elliptic & $\mathrm{n}$ & none & $\mathrm{D} / \mathrm{B}$ & 71 & 2 & & \\
\hline HUN1 & prudo20 & Duránci & $26-40$ & ovate & violet/blue & wide, blackish & E & 72 & 2 & & \\
\hline FRA16 & P3705 & Saint-Léonard & $<10$ & drop-shaped & violet/blue & wide, violet & $\mathrm{D} / \mathrm{B}$ & 73 & 2 & & \\
\hline
\end{tabular}




\begin{tabular}{|c|c|c|c|c|c|c|c|c|c|c|c|}
\hline DEU2 & PFL0010 & Ersinger Frühzwetsche & $11-25$ & elliptic & $\begin{array}{l}\text { violet/blue } \\
\text { yellow/gree }\end{array}$ & wide, violet & $\mathrm{P} / \mathrm{Z}$ & 74 & 2 & (4) & \\
\hline ITA11 & 240 & Sanacore & $11-25$ & obovate & $\mathrm{n}$ & none & $\mathrm{D} / \mathrm{B}$ & 75 & 2 & & \\
\hline ITA13 & 59 & Caleca & $11-25$ & elliptic & $\begin{array}{l}\text { green } \\
\text { yellow/gree }\end{array}$ & medium, red & $\mathrm{D} / \mathrm{B}$ & 76 & 2 & & \\
\hline FRA12 & P1671 & Verdanne & $26-40$ & elliptic & $\mathrm{n}$ & slight, red & $\mathrm{E}$ & 77 & 2 & & \\
\hline ITA8 & $\begin{array}{l}196 \\
\text { CRA PRU }\end{array}$ & Paradisu & $26-40$ & oblong & green & slight, red & E & 78 & 2 & & \\
\hline BEL7 & 319 & Altesse Dorée & $26-40$ & ovate & orange & slight, pink & $\mathrm{P} / \mathrm{Z}$ & 79 & 2 & (4) & (3) \\
\hline SVK1 & svk-pd-001 & Kozlienka & $26-40$ & elliptic & violet/blue & none & $\mathrm{P} / \mathrm{Z}$ & 80 & 2 & & \\
\hline NOR4 & 1422 & Blåplomme fra Lier & $11-25$ & ovate & $\begin{array}{l}\text { violet/blue } \\
\text { yellow/gree }\end{array}$ & wide, black & $\mathrm{D} / \mathrm{B}$ & 81 & 2 & (3) & \\
\hline GRC4 & PD0007 & Avgata Skopelou & $26-40$ & drop-shaped & $\mathrm{n}$ & none & E & 82 & 2 & & \\
\hline DEU1 & PFL0002 & Bühler Frühzwetsche & $11-25$ & elliptic & violet/blue & none & $\mathrm{P} / \mathrm{Z}$ & 83 & 2 & (4) & \\
\hline GBR4 & $1949-225$ & Winesour & $11-25$ & elliptic & $\begin{array}{l}\text { purple/red } \\
\text { yellow/gree }\end{array}$ & wide, violet & $\mathrm{D} / \mathrm{B}$ & 84 & 2 & & \\
\hline FRA9 & P0410 & Quetsche de Wagenstadt & $11-25$ & elliptic & $\mathrm{n}$ & slight, orange & $\mathrm{P} / \mathrm{Z}$ & 85 & 2 & & \\
\hline ITA12 & 249 & Sighera & $11-25$ & elliptic & green & medium, violet & $\mathrm{D} / \mathrm{B}$ & 86 & 2 & & \\
\hline ITA3 & 216 & Ramassin Ramassin & $<10$ & oblong & $\begin{array}{l}\text { purple/red } \\
\text { yellow/gree }\end{array}$ & wide, black & $\mathrm{D} / \mathrm{B}$ & 87 & 2 & & \\
\hline HUN3 & prudo436 & Potyó fehér & $<10$ & elliptic & $\begin{array}{l}\mathrm{n} \\
\text { yellow/gree }\end{array}$ & slight, red & $\mathrm{D} / \mathrm{B}$ & 88 & 2 & & \\
\hline FRA13 & P2737 & Prune de Vars & $11-25$ & rounded flat & $\mathrm{n}$ & wide, red & G & 89 & 2 & & \\
\hline HUN5 & prudo522 & Potyó szilva & $5-15$ & elliptic & dark blue & wide, black & $\mathrm{D} / \mathrm{B}$ & 90 & 2 & & \\
\hline ITA10 & 219 & Ramassin di Pagno & $<10$ & oblong & purple/red & wide, black & $\mathrm{D} / \mathrm{B}$ & 91 & 2 & & \\
\hline FRA14 & P3344 & Prune de Chien & $11-25$ & round & dark blue & none & $\mathrm{D} / \mathrm{B}$ & 92 & 2 & & \\
\hline FRA17 & P3726 & Prune de Chien & $11-25$ & round & dark blue & none & $\mathrm{D} / \mathrm{B}$ & 93 & 2 & & \\
\hline NOR2 & 1389 & Eikerplomme & $<10$ & elliptic & orange & medium, red & $\mathrm{D} / \mathrm{B}$ & 94 & 2 & 3 & \\
\hline SRB2 & PD 0202 & Moravka & $11-25$ & elliptic & dark blue & violet & $\mathrm{D} / \mathrm{B}$ & 95 & 2 & & \\
\hline SVK4 & svk-pd-004 & 63 MY BO 1 & $11-25$ & round & purple/red & medium, red & $\mathrm{C}$ & 96 & 2 & & \\
\hline DNK5 & POM B205 & Spilling (DEU) & $<10$ & round & $\begin{array}{l}\text { orange } \\
\text { yellow/gree }\end{array}$ & medium, red & $\mathrm{D} / \mathrm{B}$ & 97 & 2 & 3 & \\
\hline DEU7 & PFL0014 & Haferpflaume & $11-25$ & elliptic & $\begin{array}{l}\mathrm{n} \\
\text { yellow/gree }\end{array}$ & none & $\mathrm{D} / \mathrm{B}$ & 98 & 2 & (4) & (3) \\
\hline BEL2 & CRA PRU 88 & Sainte-Catherine & $26-40$ & oblong & $\mathrm{n}$ & slight, red & $\mathrm{P} / \mathrm{Z}$ & 99 & 2 & (4) & (3) \\
\hline ITA14 & 62 & Cariadoggia & $11-25$ & oblong & yellow & none & $\mathrm{D} / \mathrm{B}$ & 100 & 2 & & \\
\hline ITA2 & 220 & Ramassin Giallo & $11-25$ & elliptic & yellow & none & $\mathrm{D} / \mathrm{B}$ & 101 & 2 & & \\
\hline
\end{tabular}




\begin{tabular}{|c|c|c|c|c|c|c|c|c|c|c|c|c|}
\hline SVK3 & svk-pd-003 & $55 \mathrm{~S}$ BO 1 & $11-25$ & round & violet/blue & none & $\mathrm{D} / \mathrm{B}$ & 102 & 2 & & & 2 \\
\hline SRB1 & PD 0203 & Rosička Zutka & $11-25$ & elliptic & violet/blue & violet & $\mathrm{D} / \mathrm{B}$ & 103 & 2 & & & 2 \\
\hline SRB4 & PD 0101 & Požegača (Balkan?) & $11-25$ & elliptic & dark blue & violet & $\mathrm{P} / \mathrm{Z}$ & 104 & 2 & 4 & 3 & 2 \\
\hline REF1 & & Bistrica (Balkan?) & c. $11-25$ & elliptic & $\begin{array}{l}\text { dark blue } \\
\text { yellow/gree }\end{array}$ & violet & $\mathrm{P} / \mathrm{Z}$ & 105 & 2 & 4 & 3 & 2 \\
\hline DNK1 & POM B197 & Gul Havreblomme & $26-40$ & round & $\begin{array}{l}\mathrm{n} \\
\text { yellow/gree }\end{array}$ & slight, pink & $?$ & 106 & 2 & & & 2 \\
\hline GRC5 & PD0001 & Asvestochoriou & $41-55$ & round & $\mathrm{n}$ & slight, red & $\mathrm{E}$ & 107 & 2 & (6) & & 2 \\
\hline HUN2 & prudo229 & Tölcsér koronájú & $11-25$ & oblong & dark blue & wide, black & $\mathrm{P} / \mathrm{Z}$ & 108 & 2 & 4 & 3 & 2 \\
\hline ITA7 & 189 & Muninca & $11-25$ & oblong & yellow & none & $\mathrm{D} / \mathrm{B}$ & 109 & 2 & & & 2 \\
\hline LVA5 & LVA01008 & Kārsavas & $26-40$ & round & violet/blue & wide, violet & $\mathrm{E}$ & 110 & 2 & & & 2 \\
\hline GRC7 & PD0002 & Praousti & $26-40$ & obovate & orange & none & M & 111 & 2 & & & 2 \\
\hline HUN4 & prudo 484 & Besztercei 5/a (Balkan?) & $11-25$ & oblong & dark blue & wide, black & $\mathrm{P} / \mathrm{Z}$ & 112 & 2 & 4 & 3 & 2 \\
\hline
\end{tabular}


Table 2. Phenotypic traits scored in situ for 104 local plum accessions according to the List of Plum Descriptors prioritized during PRUNDOC. Additional categories (italicized) were added to most of the observed traits in order to accurately classify a wide range of distinct, as well as transitional phenotypic forms found among the examined accessions.

\begin{tabular}{|c|c|}
\hline & Trait \\
\hline & Measured and derived traits \\
\hline 1. & $\begin{array}{l}\text { Fruit size: } 1=\text { very small }(<10 \mathrm{~g}), 2=\text { very small/small }(10-11 \mathrm{~g}), 3=\text { small }(11-25 \mathrm{~g}) \text {, } \\
4=\text { small/medium }(25-26 \mathrm{~g}), 5=\text { medium }(26-40 \mathrm{~g}), 7=\text { large }(41-55 \mathrm{~g}), 8=\text { very large }(56-70 \mathrm{~g}) \text {, } \\
9=\text { extremely large }(>70 \mathrm{~g})\end{array}$ \\
\hline \multirow[t]{2}{*}{2.} & Stone: ratio length-width (=thickness) \\
\hline & Observed traits \\
\hline 3. & $\begin{array}{l}\text { Season of flowering: } 1=\text { extremely early, } 2=\text { very early, } 3=\text { early, } 4=\text { early/intermediate, } \\
5=\text { intermediate, } 6=\text { intermediate/late }, 7=\text { late, } 8=\text { very late, } 9=\text { extremely late }\end{array}$ \\
\hline 4. & $\begin{array}{l}\text { Harvest maturity: } 1=\text { extremely early, } 2=\text { very early, } 3=\text { early, } 4=\text { early } / \text { mid-season; } 5=\text { mid- } \\
\text { season, } 6=\text { mid-season/late, } 7=\text { late, } 8=\text { very late, } 9=\text { extremely late }\end{array}$ \\
\hline 5. & $\begin{array}{l}\text { Fruit shape: } 1=\text { rounded flat, } 2=\text { round, } 3=\text { elliptic, } 4=\text { elongated elliptic, } 5=\text { ovate, } 6=\text { heart } \\
\text { shaped, } 7=\text { drop shaped, } 8=\text { inverted ovate }\end{array}$ \\
\hline 6. & $\begin{array}{l}\text { Fruit skin colour: } 1=\text { whitish, } 2=\text { green, } 3=\text { yellow/green, } 4=\text { yellow/green/orange, } 5=\text { orange, } \\
7=\text { purple/red, } 8=\text { violet/blue, } 9=\text { dark blue }\end{array}$ \\
\hline 7. & $\begin{array}{l}\text { Over colour of the skin: } 0=\text { none, } 1=\text { orange, } 2=\text { pink, } 5=\text { red, } 6=\text { red } / \text { violet, } 7=\text { violet, } \\
8=\text { violet/black, } 9=\text { black }\end{array}$ \\
\hline 8. & Stone adherence to flesh: $1=$ freestone, $2=$ semi-freestone, $3=$ clingstone \\
\hline 9. & $\begin{array}{l}\text { Stone shape: } 1=\text { rounded flat, } 2=\text { rounded flat } / \text { rounded }, 3=\text { rounded, } 4=\text { rounded } / \text { ovate, } 5=\text { ovate, } \\
7=\text { elliptic, } 9=\text { elongated }\end{array}$ \\
\hline 10. & Colour of flesh: $1=$ whitish, $2=$ green, $3=$ yellowish green, $4=$ yellow, $5=$ orange, $6=$ red \\
\hline 11. & $\begin{array}{l}\text { Sensory analysis of sugar acid ratio: } 1=\text { very acidic, } 3=\text { acidic, } 4=\text { acidic } / \text { good balance, } 5=\text { good } \\
\text { balance, } 6=\text { good balance/sweet, } 7=\text { sweet, } 9=\text { very sweet }\end{array}$ \\
\hline 12. & $\begin{array}{l}\text { Flesh firmness: } 1=\text { extremely soft, } 3=\text { soft, } 4=\text { soft/medium, } 5=\text { =medium, } 6=\text { medium/firm, } \\
7=\text { firm, } 9=\text { extremely firm }\end{array}$ \\
\hline 13. & $\begin{array}{l}\text { Fruit: depth of suture towards stalk end: } 1=\text { absent, } 2=\text { absent } / \text { shallow, } 3=\text { shallow, } \\
4=\text { shallow/medium, } 5=\text { medium, } 6=\text { medium/deep }, 7=\text { deep }\end{array}$ \\
\hline 14. & $\begin{array}{l}\text { Fruit: depth of stalk cavity: } 1=\text { absent, } 2=\text { absent } / \text { shallow, } 3=\text { shallow, } 4=\text { shallow } / \text { medium, } \\
5=\text { medium, } 7=\text { deep }\end{array}$ \\
\hline 15. & $\begin{array}{l}\text { Extent of over colour: } 1=\text { none, } 2=\text { none/slight, } 3=\text { slight, } 5=\text { medium, } 6=\text { medium/widespread, } \\
7=\text { widespread }\end{array}$ \\
\hline 16. & Fruit: skin bloom: $1=$ none, $3=$ poor, $4=$ poor $/$ medium, $5=$ medium, $6=$ medium $/$ high, $7=$ high \\
\hline 17. & $\begin{array}{l}\text { Fruit: flesh juiciness: } 2=\text { none/low, } 3=\text { low, } 4=\text { low/medium, } 5=\text { medium, } 6=\text { medium } / \text { high, } \\
7=\text { high }\end{array}$ \\
\hline 18. & Stone: size: $3=$ small, $4=$ small/medium, $5=$ medium, $6=$ medium $/$ large, $7=$ large \\
\hline 19. & Leaf blade shape: $1=$ ovale, $2=$ elliptic, $3=$ obovate \\
\hline 20. & $\begin{array}{l}\text { Tree habit: } 1=\text { upright, } 2=\text { =upright/semi-upright, } 3=\text { semi-upright, } 4=\text { semi-upright } / \text { spreading, } \\
5=\text { spreading, } 7=\text { drooping, } 9=\text { weeping }\end{array}$ \\
\hline
\end{tabular}


Table 3. Number of alleles for eight SSR loci, allele size range and Nei's gene diversity, calculated for all plum genotypes, reference cultivars, local accessions, as well as for $\mathrm{K}=2$ reconstructed panmictic populations (RPPs) and admixed accessions. For origin and DNA sequences of these loci, see Sehic et al. (2015).

\begin{tabular}{|c|c|c|c|c|c|c|c|c|c|c|c|c|c|}
\hline \multirow{2}{*}{$\begin{array}{l}\text { Locus } \\
\text { code }\end{array}$} & \multirow{2}{*}{$\begin{array}{c}\text { Size } \\
\text { range } \\
\text { (bp) }\end{array}$} & \multicolumn{2}{|c|}{ All $(n=112)$} & \multicolumn{2}{|c|}{ Reference $(n=8)$} & \multicolumn{2}{|c|}{ Local $(n=104)$} & \multicolumn{2}{|c|}{ RPP1 $(n=49)$} & \multicolumn{2}{|c|}{ RPP2 $(n=43)$} & \multicolumn{2}{|c|}{ Admixed $(n=20)$} \\
\hline & & $\begin{array}{c}\text { No } \\
\text { alleles } \\
\end{array}$ & $\begin{array}{c}\text { Gene } \\
\text { diversity }\end{array}$ & $\begin{array}{c}\text { No } \\
\text { alleles } \\
\end{array}$ & $\begin{array}{c}\text { Gene } \\
\text { diversity }\end{array}$ & $\begin{array}{c}\text { No } \\
\text { alleles } \\
\end{array}$ & $\begin{array}{c}\text { Gene } \\
\text { diversity }\end{array}$ & $\begin{array}{c}\text { No } \\
\text { alleles } \\
\end{array}$ & $\begin{array}{c}\text { Gene } \\
\text { diversity }\end{array}$ & $\begin{array}{c}\text { No } \\
\text { alleles } \\
\end{array}$ & $\begin{array}{c}\text { Gene } \\
\text { diversity }\end{array}$ & No alleles & $\begin{array}{c}\text { Gene } \\
\text { diversity }\end{array}$ \\
\hline $\begin{array}{c}\text { UDP } \\
98-407\end{array}$ & $157 / 231$ & 29 & 0.886 & 10 & 0.912 & 29 & 0.885 & 14 & 0.8651 & 25 & 0.8956 & 10 & 0.8628 \\
\hline $\begin{array}{c}\text { Pac A } \\
33\end{array}$ & $169 / 254$ & 38 & 0.932 & 15 & 0.909 & 38 & 0.932 & 28 & 0.8938 & 21 & 0.9002 & 25 & 0.9489 \\
\hline $\begin{array}{c}\text { CPSCT } \\
026\end{array}$ & $165 / 216$ & 23 & 0.916 & 13 & 0.904 & 23 & 0.917 & 17 & 0.8973 & 21 & 0.9196 & 18 & 0.9282 \\
\hline $\begin{array}{c}\text { BPPCT } \\
040\end{array}$ & $118 / 154$ & 17 & 0.878 & 8 & 0.883 & 17 & 0.878 & 10 & 0.8477 & 17 & 0.8983 & 14 & 0.8865 \\
\hline $\begin{array}{c}\text { BPPCT } \\
007\end{array}$ & $121 / 159$ & 19 & 0.910 & 10 & 0.898 & 19 & 0.911 & 13 & 0.8992 & 19 & 0.9106 & 14 & 0.8992 \\
\hline $\begin{array}{c}\text { BPPCT } \\
014\end{array}$ & $186 / 289$ & 47 & 0.934 & 16 & 0.939 & 47 & 0.934 & 22 & 0.9171 & 40 & 0.9397 & 27 & 0.9263 \\
\hline $\begin{array}{c}\text { BPPCT } \\
034\end{array}$ & $213 / 277$ & 27 & 0.915 & 12 & 0.914 & 27 & 0.915 & 17 & 0.8979 & 24 & 0.9215 & 18 & 0.9181 \\
\hline $\begin{array}{c}\text { UDP } \\
96-005\end{array}$ & $092 / 169$ & 34 & 0.917 & 11 & 0.858 & 34 & 0.920 & 15 & 0.8928 & 28 & 0.9137 & 20 & 0.9315 \\
\hline Mean & & 29.25 & 0.911 & 11.88 & 0.902 & 29.25 & 0.912 & 17.00 & 0.8889 & 24.38 & 0.9124 & 18.25 & 0.9127 \\
\hline
\end{tabular}




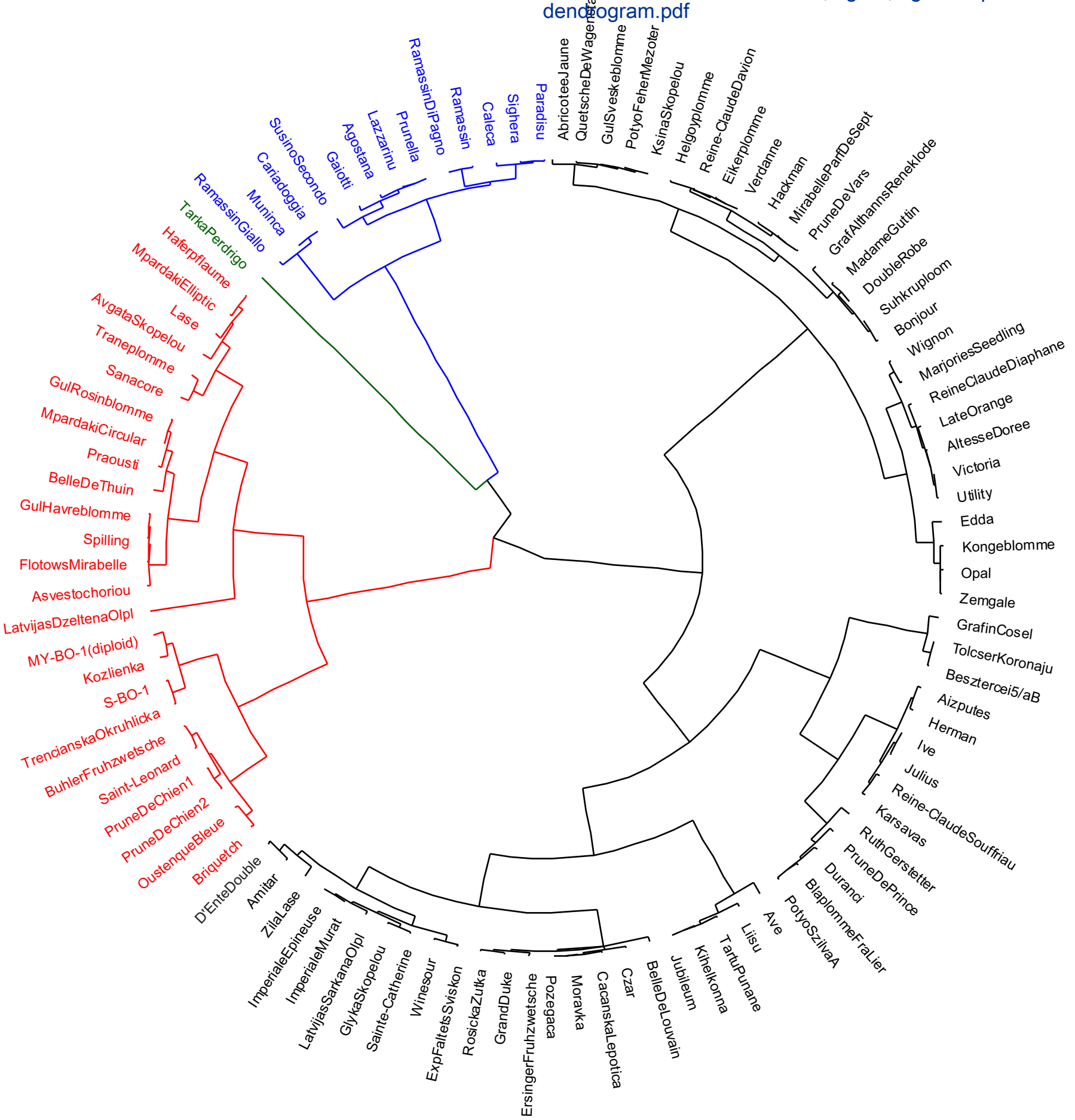




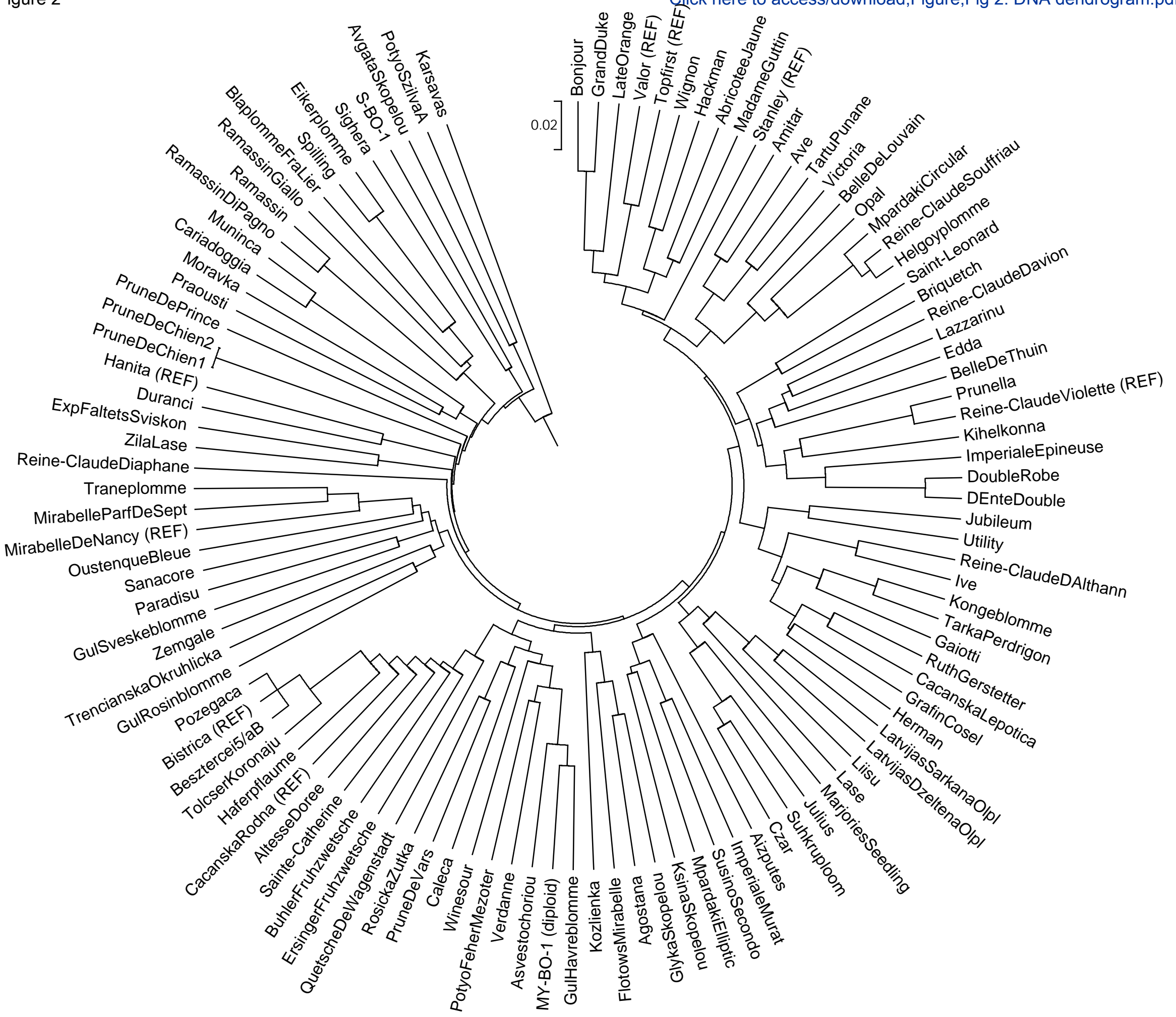




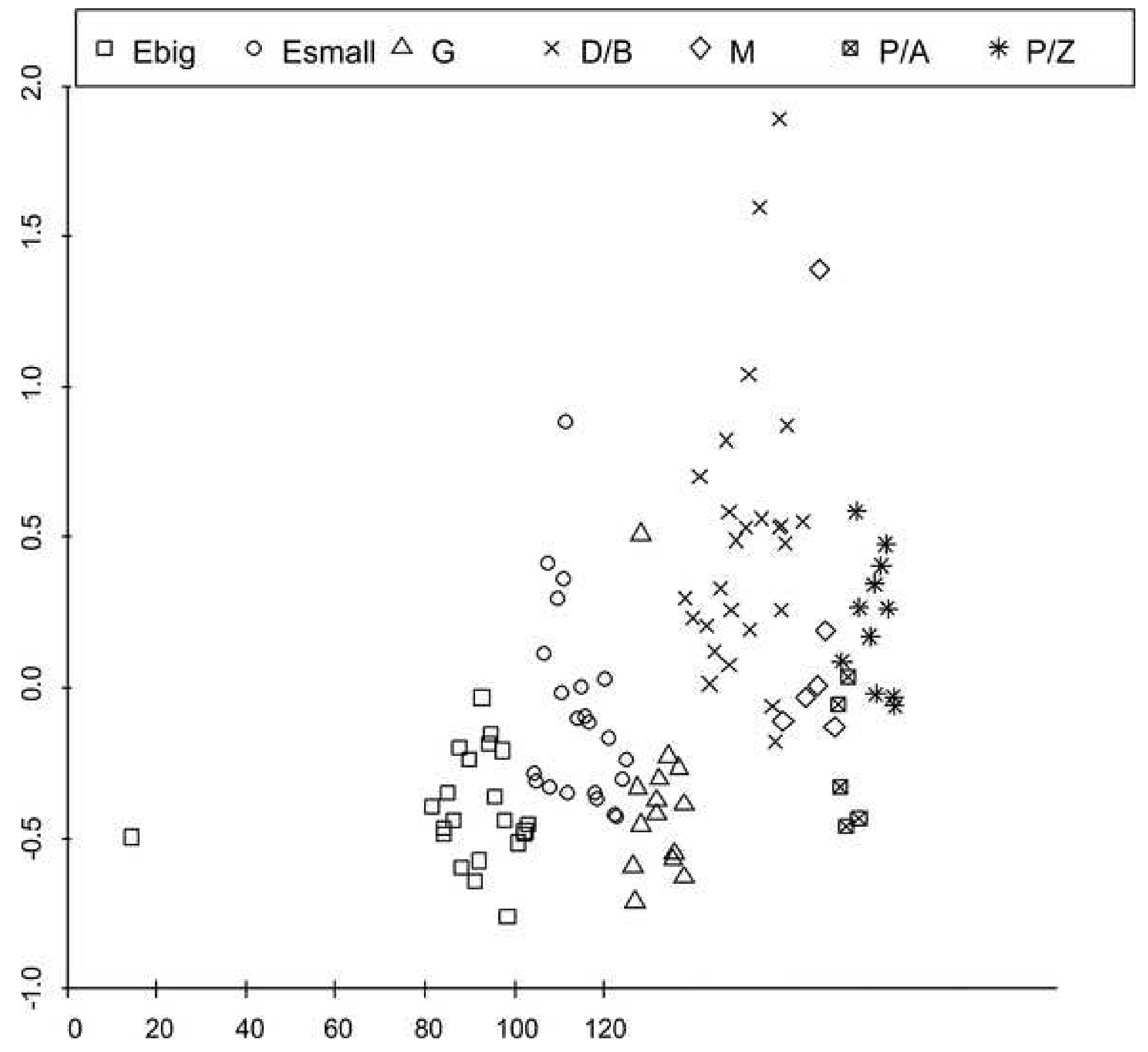




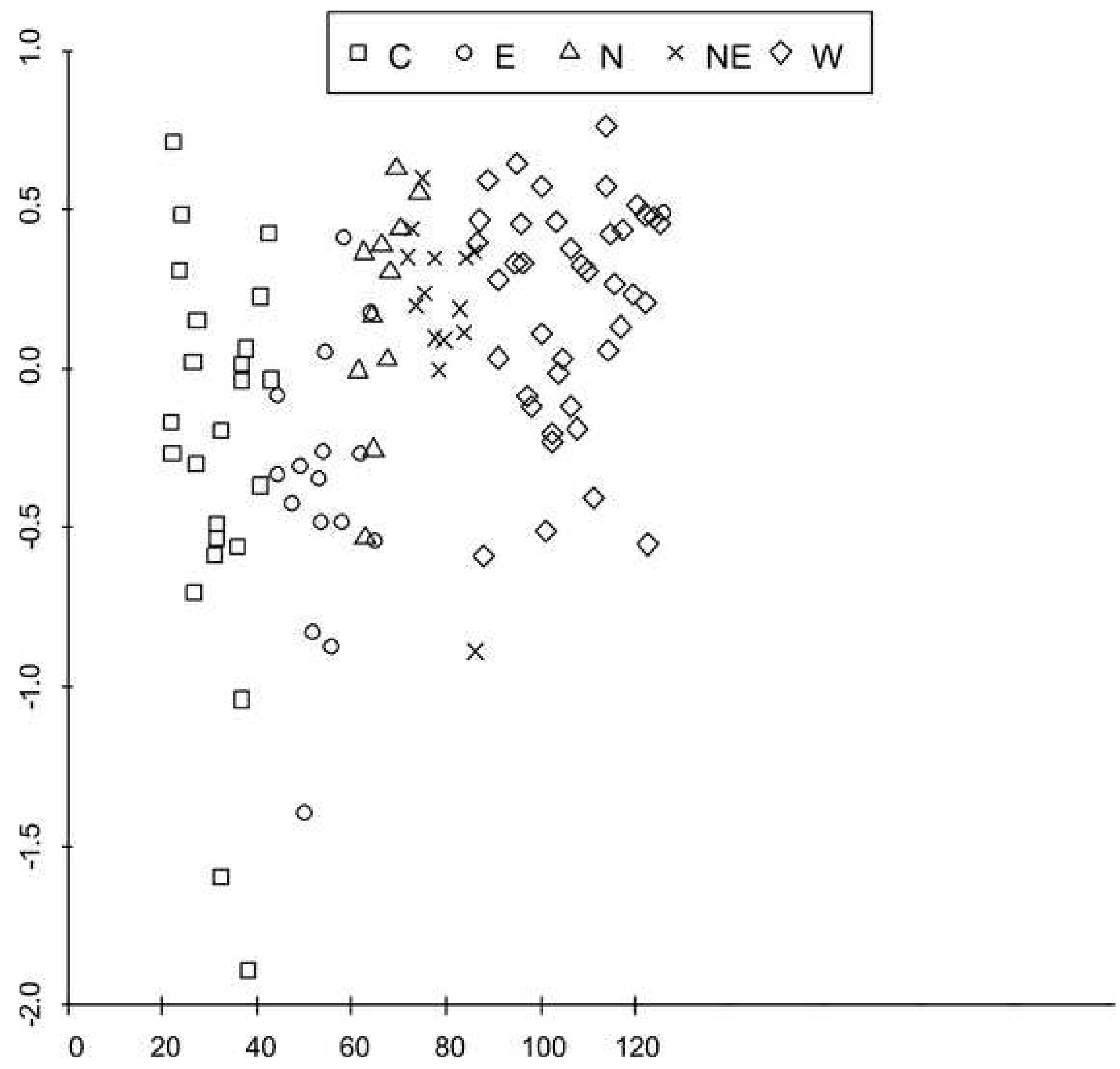


a)

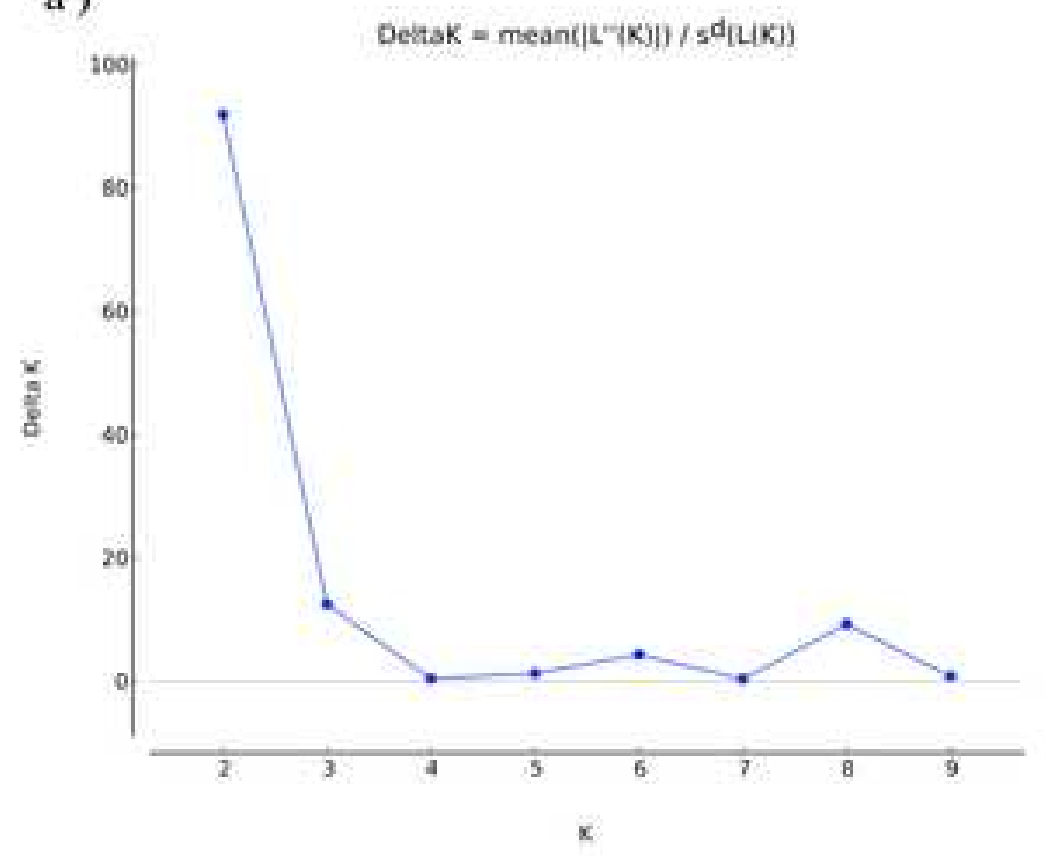

b)

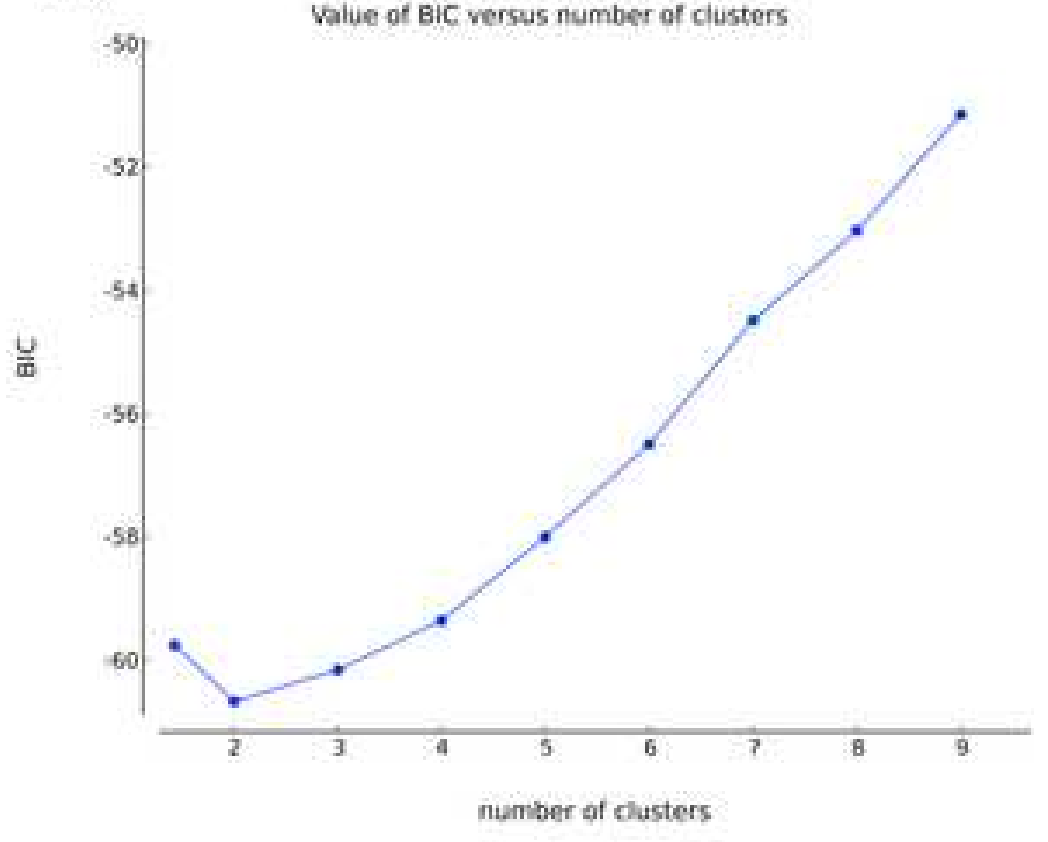




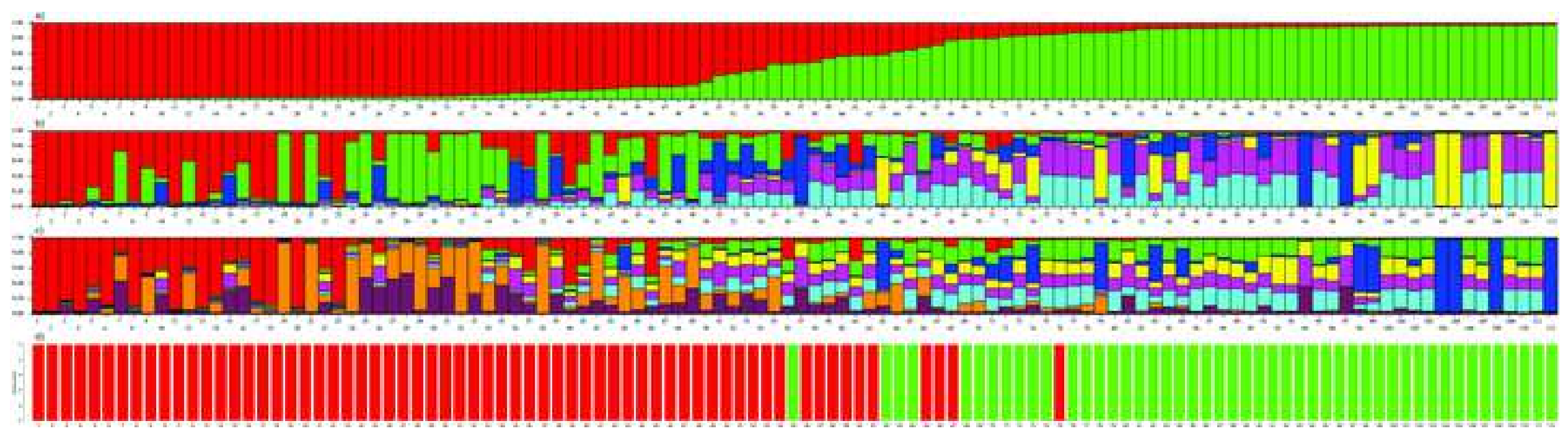


Click here to view linked References

Click here to access/download attachment to manuscript Supplementary data revised 2020.xlsx 